\title{
An Update on the Exploratory Use of Curcumin in Neuropsychiatric Disorders
}

\author{
Nicolás Lamanna-Rama ${ }^{1,2,+} \mathbb{D}_{\mathbb{D}}$, Diego Romero-Miguel ${ }^{1,2,+} \mathbb{D}^{\mathbb{D}}$, Manuel Desco $^{1,2,3,4, * \mathbb{D}}$ \\ and Maria Luisa Soto-Montenegro $1,3,5, *$ (D)
}

1 Instituto de Investigación Sanitaria Gregorio Marañón, 28007 Madrid, Spain; nlamanna@hggm.es (N.L.-R.); ldromero@hggm.es (D.R.-M.)

2 Departamento de Bioingeniería e Ingeniería Aeroespacial, Universidad Carlos III de Madrid, 28911 Madrid, Spain

3 Centro de Investigación Biomédica en Red de Salud Mental (CIBERSAM), 28029 Madrid, Spain

4 Centro Nacional de Investigaciones Cardiovasculares (CNIC), 28029 Madrid, Spain

5 High Performance Research Group in Physiopathology and Pharmacology of the Digestive System (NeuGut), Universidad Rey Juan Carlos, Alcorcón, 28922 Madrid, Spain

* Correspondence: desco@hggm.es (M.D.); marisa@hggm.es (M.L.S.-M.)

+ These authors contributed equally to this work.

check for updates

Citation: Lamanna-Rama, N.; Romero-Miguel, D.; Desco, M.; Soto-Montenegro, M.L. An Update on the Exploratory Use of Curcumin in Neuropsychiatric Disorders. Antioxidants 2022, 11, 353. https:// doi.org/10.3390/antiox11020353

Academic Editor: John T. Weber

Received: 28 January 2022

Accepted: 8 February 2022

Published: 10 February 2022

Publisher's Note: MDPI stays neutral with regard to jurisdictional claims in published maps and institutional affiliations.

Copyright: (C) 2022 by the authors. Licensee MDPI, Basel, Switzerland. This article is an open access article distributed under the terms and conditions of the Creative Commons Attribution (CC BY) license (https:// creativecommons.org/licenses/by/ $4.0 /)$.

\begin{abstract}
Curcumin is a polyphenol extracted from the rhizome of the turmeric plant. Beyond its common use as a culinary spice in Eastern Asia, curcumin has been proposed as a therapeutic compound due to its antioxidant, anti-inflammatory and neuroprotective properties. Thus, its efficacy has been evaluated in various inflammatory-based psychiatric disorders, such as schizophrenia, depression, or autism. Our aim is to review those preclinical and clinical studies carried out in psychiatric disorders whose therapeutic approach has involved the use of curcumin and, therefore, to discern the possible positive effect of curcumin in these disorders. Preclinical studies and completed clinical trials of curcumin for psychiatric disorders published from January 2005 to October 2021 were identified through searching relevant databases until 31st October 2021. Sixty-five preclinical studies and 15 clinical trials and open-label studies were selected. Results showed a bias toward studies in depression and, to a lesser extent, schizophrenia. In all disorders, the results were positive in reducing psychiatric deficits. Despite the considerable number of beneficial outcomes reported, the small number of trials and the heterogeneity of protocols make it difficult to draw solid conclusions about the real potency of curcumin in psychiatric disorders.
\end{abstract}

Keywords: curcumin; psychiatric disorders; inflammation; oxidative stress; schizophrenia; autism; depression; Obsessive Compulsive Disorder

\section{Introduction}

Turmeric (Curcuma longa) is an herbaceous plant widely used in Asia as a dye, culinary spice, and as a traditional natural therapeutic compound [1]. The rhizome of this plant, also called turmeric, is enriched with yellow dyes, the curcuminoids [2]. Within this family of compounds, curcumin is considered one of the most relevant. Curcumin, the active compound of turmeric, is a polyphenol that has also been largely used as a remedy for different pathologies in Asia for several decades due to its healthy and biopharmacological properties, and its lack of adverse effects, even at high doses. Moreover, curcumin has been reported to have anti-inflammatory, antioxidant, neuroprotective, and even anti-aging and antineoplasic properties [3-7] (Figure 1). Curcumin may exert its anti-inflammatory and antioxidant (anti-IOS) effects by influencing the synthesis of some IOS regulators, such as heme-oxygenase-1 (HO1), glutathione (GSH), catalase (CAT), and superoxide dismutase (SOD) [8]. These properties cause curcumin to have an impact on those diseases in which IOS regulation does not work correctly and are related to the disease appearance. Thus, 
curcumin may exert a beneficial effect on the immune system, reducing B lymphocyte proliferation by inhibiting B lymphocyte stimulator (BLYS).

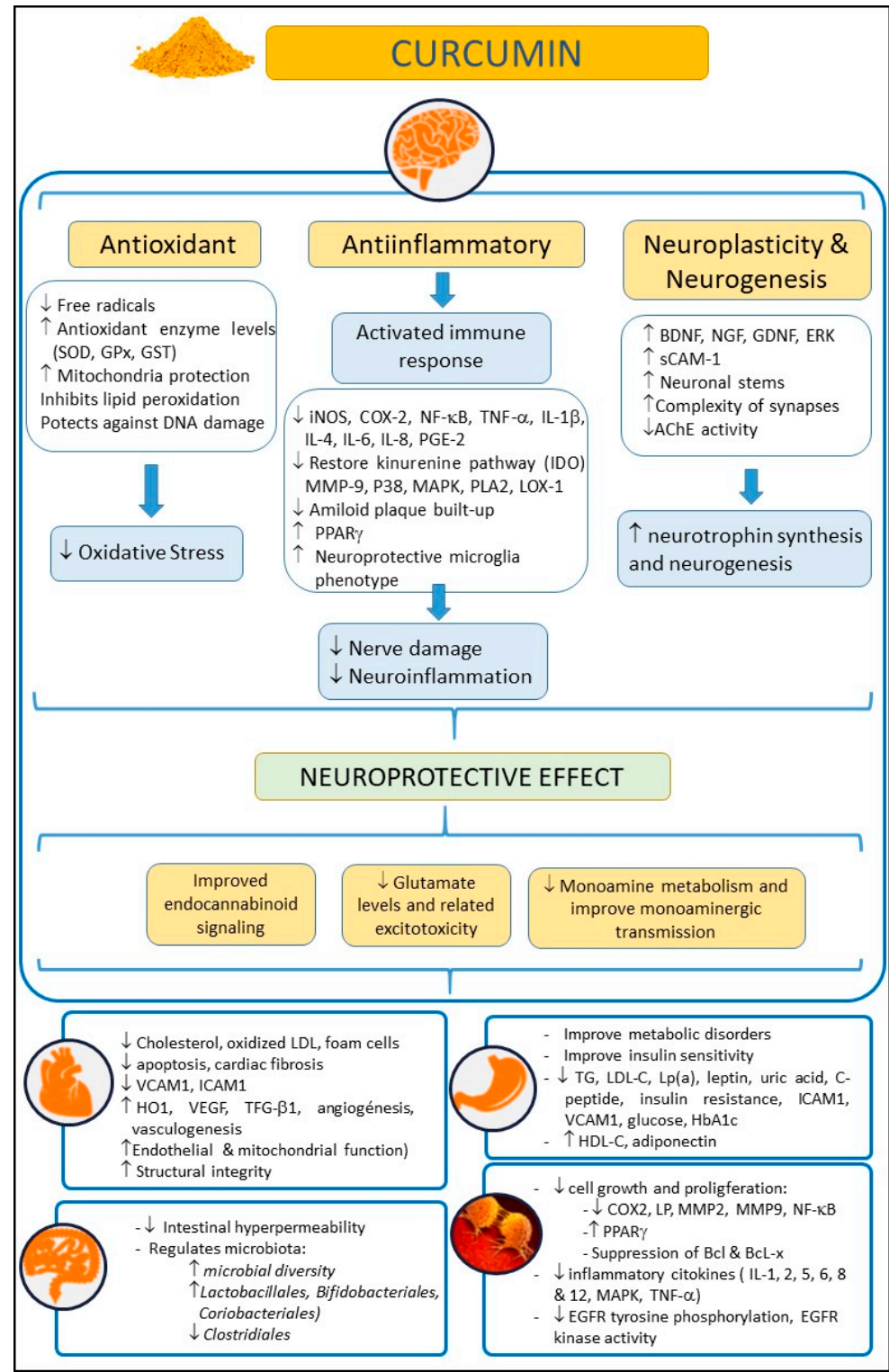

Figure 1. Summary of potential beneficial effects of curcumin on health, in neurological, cardiovascular, intestinal, metabolic, and oncological disorders. Abbreviations: AChE: acetylcholinesterase; Bcl: B-cell lymphoma; BDNF: brain-derived neurotrophic factor; COX-2: cyclooxygenase 2; EGFR: epidermal growth factor receptor; ERK: extracellular-regulated kinase; 9 GDNF: glial cell line-derived neurotrophic factor; GPx: glutathione peroxidase; GSH: glutathione; GST: glutathione S-transferase; HbA1c: glycosylated hemoglobin A1c; HDL-C: high density lipoprotein cholesterol; HO-1: hemeoxygenase-1; ICAM-1: intercellular adhesion molecule-1; IL: interleukin; iNOS: inducible nitric oxide synthase; IL-10: Interleukin-10; LDL-C: low density lipoprotein cholesterol; LOX-1: lectin-like oxidized low-density lipoprotein receptor-1; Lp(a): lipoprotein(a); LP: lipoxygenase; MAPK: mitogenactivated protein kinase; MMP-9: matrix metalloproteinase 9; NF- $\mathrm{BB}$ : nuclear factor kappa-B; NGF: Nerve growth factor; PLA2: phospholipase A2; P38: p38 MAKP; PGE-2: prostaglandin E2; PPAR $\gamma$ : peroxisome proliferator-activated receptor gamma; sCAM-1: soluble cell adhesion molecule 1; TG: triglycerides; TNF- $\alpha$ : tumor necrosis factor- $\alpha$; TGF- $\beta 1$ : transforming growth factor; SOD: superoxide dismutase; VCAM-1: vascular cell adhesion molecule-1; VEGF: vascular endothelial growth factor. 
Curcumin can also reduce the neutrophil recruitment to areas affected by inflammation [9], and can also increase the phagocytic activity of macrophages [10]. Furthermore, curcumin has proven to be an effective modulator of the endocrine system, enhancing the uptake or regulating some hormones, such as insulin [11]. All these properties have boosted the interest of researchers in this compound in recent decades. Thus, several preclinical studies and clinical trials have been conducted [12] with the aim of elucidating whether or not curcumin was effective for many different diseases, such as skin [13], cancer, or neurological pathologies [5].

Recently, curcumin has also been used in different psychiatric disorders due to the likely involvement of IOS processes in their onset and evolution. In this sense, the abovedescribed role of curcumin as an anti-IOS drug made this compound a good candidate to halt or palliate the course of these diseases. This is especially important, as current therapeutic strategies for many psychiatric disorders have a relatively high failure rate. Thus, the search for new approaches to help address this problem is ongoing.

So far, several clinical trials and studies with animal models, which we will detail in depth in the following sections of this work, have reported the efficacy of curcumin in some psychiatric disorders, such as depression, schizophrenia, or autism. However, some studies have showed no positive effects of curcumin in neurological diseases. The main and most recommended route of administration of curcumin is oral and, despite considerable high absorption through lipid membranes caused by its lipophilic nature, curcumin has a low bioavailability after being metabolized, accumulating in the spleen, liver, and intestine, with a low uptake in the rest of the organs $[8,14,15]$. The low absorption by the small intestine and the high metabolism in the liver weaken its oral bioavailability [16], making it necessary to use high oral doses of curcumin to reach other target organs such as the brain [16]. Moreover, its apparent ineffectiveness in interacting specifically with a single pharmacological target has prompted the classification of curcumin as a pan assay interference compound (PAINS) and an invalid metabolic panacea (IMPS) [17,18]. However, despite the poor pharmacokinetics of this compound, the existence of positive results in several studies raises the question of how curcumin could cause a beneficial effect at the brain level despite being barely able to reach this organ. A recent hypothesis explains that curcumin could be acting on the gut microbiota [19] since the intestine and liver are primary sites of metabolism for curcumin [16], reducing intestinal inflammation and, hence, functioning as a neuroprotective agent due to the likely involvement of neuroinflammation in many psychiatric disorders in which alterations of the gut-brain axis play an important role $[2,20]$. Furthermore, in order to address the low bioavailability of the curcumin, new formulations of this compound are being synthetized to improve its pharmacokinetics and achieve stable curcumin that can reach the brain in a higher concentration. Some of them are based on conjugating curcumin with lipids or co-treating it with piperine, a bio-enhancer that improves the absorption of curcumin $[8,21]$. A recent emerging and promising strategy to improve its bioavailability in the brain combines curcumin with drug delivery carriers such as liposomes, exosomes, magnetic particles or ultrasound bubbles [22]. Moreover, some of these exosomes have shown an anti-inflammatory capacity [23], which could enhance the anti-inflammatory effect of curcumin in the brain and other organs of interest. Of note, oral and intra-nasal administration of nanoparticles are also being explored, which could increase drug absorption in the brain, representing a great advantage in brain disorders [24,25].

Therefore, the aim of this work is to review the current literature on the effect of curcumin and its derivatives in the field of psychiatric disorders, and to discern whether the initial enthusiasm for this compound is well-founded [21,26].

\section{Materials and Methods}

A non-systematic literature review was performed in relevant databases until 31st October 2021 (https://ncbi.nlm.nih.gov/pubmed/, https:/ / clinicaltrials.gov/, accessed on 31 October 2021). The data search covered a range from January 2005 to October 2021 (no 
studies prior 2005 were found). Published English-language studies investigating the effects of curcumin on neuropsychiatric pathologies were included. The search terms used as keywords are listed in the Appendix. All open-label clinical studies (OLS) and randomized clinical trials (RCTs) (Table 1) and preclinical studies (Table 2) that met the search terms were included. For contextualization purposes, one case report was mentioned to explain the rationale for larger trials. Figure 2 shows a scheme with the number of studies for each disorder included in this review. The most commonly used abbreviations can be found in Abbreviation.

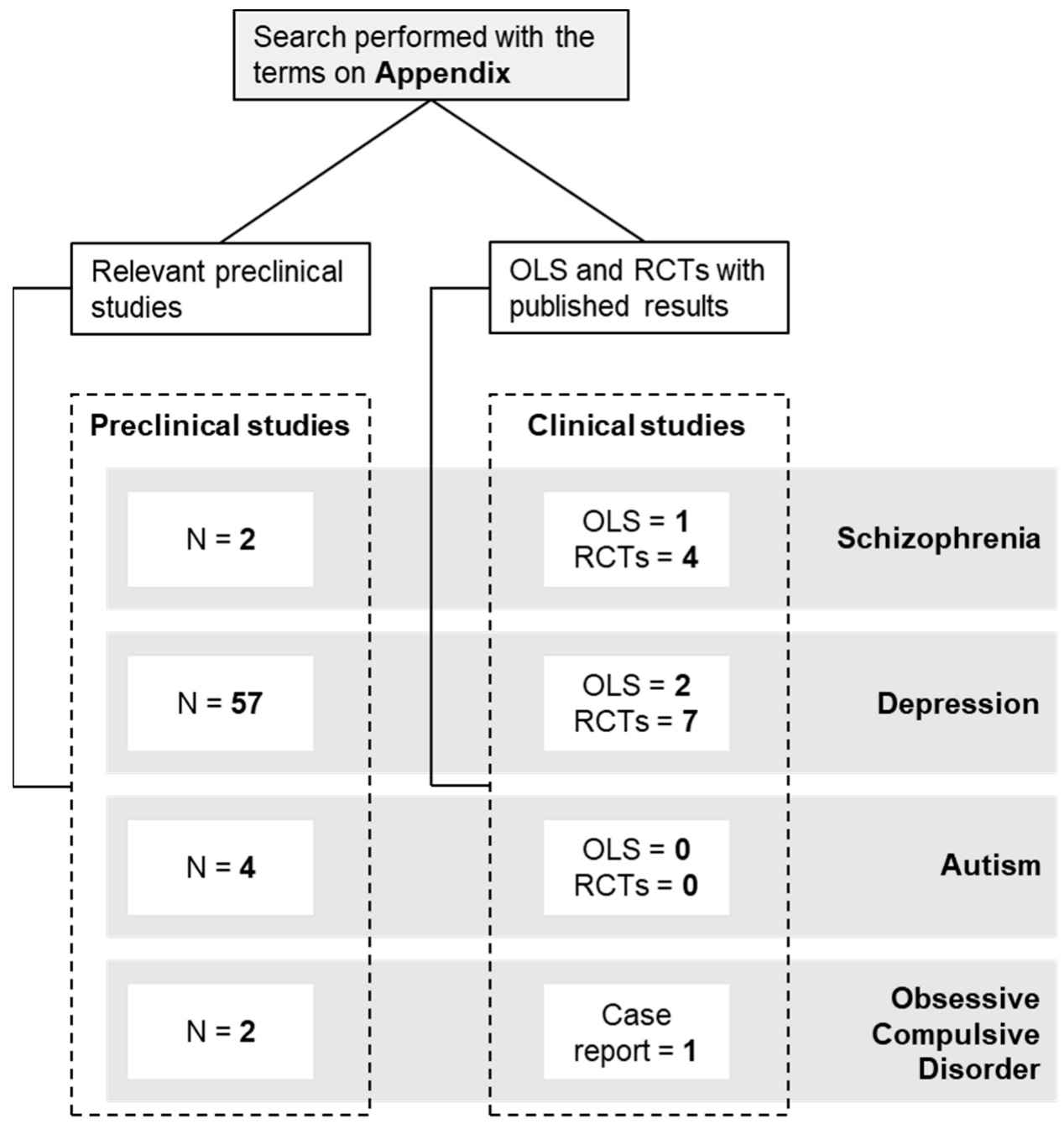

Figure 2. Selected preclinical studies, open-label studies and clinical trials. 
Table 1. Clinical studies and trials in neuropsychiatric diseases.

\begin{tabular}{|c|c|c|c|c|c|c|c|c|c|c|c|c|}
\hline Disease & Authors & Type & Phase & N Patients & Type Patients & Country & Duration & Dosage & $\begin{array}{c}\text { Other } \\
\text { Treatment }\end{array}$ & $\begin{array}{c}\text { Biological } \\
\text { Effects }\end{array}$ & Clinical Efficacy & $\begin{array}{l}\text { Safety and } \\
\text { Tolerability }\end{array}$ \\
\hline \multirow{4}{*}{ Schizophrenia } & NCT01875822 & $\begin{array}{l}\text { Open-label } \\
\text { study }\end{array}$ & $1-2$ & 17 & $\begin{array}{l}\text { Schizophrenia } \\
\text { patients }\end{array}$ & Puerto Rico & 16 weeks & $\begin{array}{c}1000 \text { or } 4000 \\
\text { mg CUR }\end{array}$ & $\begin{array}{c}5 \mathrm{mg} \text { Bioperine } \\
+ \\
\text { Antipsychotic }\end{array}$ & - & - & - \\
\hline & $\begin{array}{c}\text { Kucukgoncu } \\
\text { et al., 2019 } \\
\text { (NCT02476708) }\end{array}$ & $\begin{array}{l}\text { Randomized, } \\
\text { double-blind, } \\
\text { placebo- } \\
\text { controlled, } \\
\text { add-on study }\end{array}$ & - & $\begin{array}{c}12 \text { (6 CUR, } 6 \\
\text { placebo) }\end{array}$ & $\begin{array}{l}\text { Schizophrenia } \\
\text { outpatients }\end{array}$ & United States & 8 weeks & $\begin{array}{l}180 \mathrm{mg} / \text { day of } \\
\text { Theracurcumin }\end{array}$ & $\begin{array}{c}\text { Usual } \\
\text { antipsychotic } \\
\text { medication }\end{array}$ & $\begin{array}{l}\text { Reduction in } \\
\text { IL-6 in CUR } \\
\text { SCZ patients }\end{array}$ & $\begin{array}{c}\text { Significant } \\
\text { improvement in } \\
\text { working memory. } \\
\text { No significant } \\
\text { improvement in } \\
\text { cognitive domains, } \\
\text { negative symptoms } \\
\text { and total PANSS }\end{array}$ & $\begin{array}{l}\text { No significant } \\
\text { adverse events }\end{array}$ \\
\hline & $\begin{array}{c}\text { Miodownik } \\
\text { et al., 2019 } \\
\text { (NCT02298985) }\end{array}$ & $\begin{array}{l}\text { Randomized, } \\
\text { double-blind, } \\
\text { placebo- } \\
\text { controlled, } \\
\text { add-on }\end{array}$ & 4 & $\begin{array}{l}38 \text { (20 CUR, } 18 \\
\text { placebo) }\end{array}$ & $\begin{array}{l}\text { Schizophrenia } \\
\text { outpatients }\end{array}$ & Israel & 24 weeks & 3000 mg/day & $\begin{array}{c}\text { Usual } \\
\text { antipsychotic } \\
\text { medication }\end{array}$ & - & $\begin{array}{l}\text { Improvement in } \\
\text { total PANSS and in } \\
\text { the negative } \\
\text { symptoms subscale. } \\
\text { No changes in } \\
\text { positive and } \\
\text { general PANSS } \\
\text { subscales nor the } \\
\text { CDSS }\end{array}$ & $\begin{array}{l}\text { No significant } \\
\text { adverse events }\end{array}$ \\
\hline & $\begin{array}{l}\text { Hosseininasab } \\
\text { et al., } 2021\end{array}$ & $\begin{array}{l}\text { Randomized, } \\
\text { double-blind, } \\
\text { placebo- } \\
\text { controlled, } \\
\text { add-on trial }\end{array}$ & - & $\begin{array}{c}56 \text { (28 CUR, } 28 \\
\text { placebo) }\end{array}$ & $\begin{array}{l}\text { Chronic and } \\
\text { stable } \\
\text { schizophrenia } \\
\text { inpatients }\end{array}$ & Iran & 16 weeks & $160 \mathrm{mg} /$ day & $\begin{array}{c}\text { Usual } \\
\text { antipsychotic } \\
\text { medication }\end{array}$ & - & $\begin{array}{l}\text { Improvement in } \\
\text { total PANSS and in } \\
\text { the negative } \\
\text { symptoms subscale, } \\
\text { general } \\
\text { psychopathology } \\
\text { subscale, positive } \\
\text { subscale, total } \\
\text { PNSS, CGI-S, and } \\
\text { CGI-I. No changes } \\
\text { in Extrapiramidal } \\
\text { symptom rating } \\
\text { scales nor CDSS }\end{array}$ & $\begin{array}{l}\text { No significant } \\
\text { adverse events }\end{array}$ \\
\hline
\end{tabular}


Table 1. Cont.

\begin{tabular}{|c|c|c|c|c|c|c|c|c|c|c|c|c|}
\hline Disease & Authors & Type & Phase & N Patients & Type Patients & Country & Duration & Dosage & $\begin{array}{c}\text { Other } \\
\text { Treatment }\end{array}$ & $\begin{array}{c}\text { Biological } \\
\text { Effects }\end{array}$ & $\begin{array}{l}\text { Clinical } \\
\text { Efficacy }\end{array}$ & $\begin{array}{l}\text { Safety and } \\
\text { Tolerability }\end{array}$ \\
\hline \multirow{5}{*}{ Depression } & $\begin{array}{l}\text { Sanmukhani } \\
(2013) \\
\text { NCT01022632 }\end{array}$ & $\begin{array}{l}\text { Randomized } \\
\text { control trial }\end{array}$ & - & $\begin{array}{c}51(17 \\
\text { fluoxentine, } 16 \\
\text { CUR, } 18 \\
\text { fluoxentine + } \\
\text { CUR) }\end{array}$ & $\begin{array}{l}\text { MDD patients } \\
(>18 \text { years })\end{array}$ & India & 6 weeks & $\begin{array}{l}1000 \mathrm{mg} / \text { day } \\
\text { of CUR; } 20 \\
\mathrm{mg} / \text { day of } \\
\text { Fluoxentine }\end{array}$ & $\begin{array}{c}\text { Paracetamol } \\
\text { and diazepam }\end{array}$ & Not described & $\begin{array}{l}\text { No significant } \\
\text { effects } \\
\text { produced by } \\
\text { curcumin or its } \\
\text { combination } \\
\text { with } \\
\text { fluoxentine } \\
\text { (HDRS) }\end{array}$ & $\begin{array}{l}\text { Curcumine } \\
\text { was well } \\
\text { tolerated }\end{array}$ \\
\hline & $\begin{array}{c}\text { Bergman } \\
(2013) \\
\text { NCT01750359 }\end{array}$ & $\begin{array}{l}\text { Randomized, } \\
\text { double-blind, } \\
\text { placebo- } \\
\text { controlled, } \\
\text { pilot clinical } \\
\text { trial }\end{array}$ & 4 & $\begin{array}{c}39 \text { (19 CUR, } 20 \\
\text { plecebo) }\end{array}$ & $\begin{array}{l}\text { MDD patients } \\
\text { (20-81 years) }\end{array}$ & Israel & 5 weeks & 500 mg/day & $\begin{array}{c}\text { Escitalopram } \\
\text { and } \\
\text { venlafaxine XR }\end{array}$ & Not described & $\begin{array}{l}\text { No effects of } \\
\text { curcumin } \\
\text { (MADRS and } \\
\text { HDRS) }\end{array}$ & $\begin{array}{l}\text { No adverse } \\
\text { effects during } \\
\text { the treatment }\end{array}$ \\
\hline & Lopresti (2014) & $\begin{array}{l}\text { Randomized, } \\
\text { double-blind, } \\
\text { placebo- } \\
\text { controlled } \\
\text { trial }\end{array}$ & - & $\begin{array}{c}25 \text { (curcumine } \\
1000 \mathrm{mg} / \text { day) } \\
27 \text { (placebo) }\end{array}$ & $\begin{array}{l}\text { MDD patients } \\
\text { (20-65 years) }\end{array}$ & Australia & 8 weeks & $1000 \mathrm{mg} /$ day & $\begin{array}{l}\text { SSRIs and } \\
\text { SNRIs }\end{array}$ & Not described & $\begin{array}{c}\text { Long-term } \\
\text { improvement } \\
\text { in IDS-SR30 } \\
\text { total scores. } \\
\text { Long-term } \\
\text { improvement } \\
\text { in STAI anxiety } \\
\text { scores }\end{array}$ & $\begin{array}{l}\text { Minor severity } \\
\text { side effects }\end{array}$ \\
\hline & Panahi (2015) & $\begin{array}{l}\text { Open-label } \\
\text { study }\end{array}$ & - & $\begin{array}{c}111(61 \text { CUR + } \\
\text { piperine, } 50 \\
\text { placebo) }\end{array}$ & $\begin{array}{l}\text { MDD patients } \\
\text { (18-65 years) }\end{array}$ & Iran & 6 weeks & $\begin{array}{c}1000 \mathrm{mg} / \text { day } \\
\text { of CUR + 10 } \\
\mathrm{mg} / \text { day of } \\
\text { piperine }\end{array}$ & $\begin{array}{l}\text { TCAs, BZDs, } \\
\text { SSRIs and } \\
\text { SNRIs }\end{array}$ & Not described & $\begin{array}{l}\text { Improvements } \\
\text { in HADS total } \\
\text { score. } \\
\text { Reductions in } \\
\text { BDI-II total } \\
\text { score }\end{array}$ & Not described \\
\hline & Yu (2015) & $\begin{array}{l}\text { Randomized, } \\
\text { double-blind, } \\
\text { placebo- } \\
\text { controlled } \\
\text { pilot study }\end{array}$ & - & $\begin{array}{l}100 \text { (50 CUR, } \\
50 \text { placebo) }\end{array}$ & $\begin{array}{l}\text { MDD patients } \\
\text { (31-59 years) }\end{array}$ & China & 6 weeks & $\begin{array}{l}500 \text { or } 1000 \\
\text { mg/day of } \\
\text { CUR; } 30 \\
\text { mg/day of } \\
\text { Saffron }\end{array}$ & Escitalopram & $\begin{array}{c}\text { Decrease in } \\
\text { IL- } 1 \beta, \text { TNF- } \alpha \\
\text { and salive } \\
\text { cortisol } \\
\text { concentrations. } \\
\text { Increase in NF } \\
\text { levels in } \\
\text { plasma }\end{array}$ & $\begin{array}{l}\text { Improvement } \\
\text { in HDRS and } \\
\text { MADR total } \\
\text { scores }\end{array}$ & $\begin{array}{l}\text { No adverse } \\
\text { effects }\end{array}$ \\
\hline
\end{tabular}


Table 1. Cont.

\begin{tabular}{|c|c|c|c|c|c|c|c|c|c|c|c|c|}
\hline Disease & Authors & Type & Phase & N Patients & Type Patients & Country & Duration & Dosage & $\begin{array}{c}\text { Other } \\
\text { Treatment }\end{array}$ & $\begin{array}{c}\text { Biological } \\
\text { Effects }\end{array}$ & $\begin{array}{l}\text { Clinical } \\
\text { Efficacy }\end{array}$ & $\begin{array}{l}\text { Safety and } \\
\text { Tolerability }\end{array}$ \\
\hline & $\begin{array}{l}\text { Lopresti and } \\
\text { Drummond } \\
\text { (2017) }\end{array}$ & $\begin{array}{l}\text { Randomized, } \\
\text { double-blind, } \\
\text { placebo- } \\
\text { controlled } \\
\text { study }\end{array}$ & - & $\begin{array}{c}123 \text { (28 CUR, } \\
33 \text { CURX2, } 26 \\
\text { CUR +Saffron, } \\
36 \text { placebo) }\end{array}$ & $\begin{array}{l}\text { MDD patients } \\
\quad(18-65)\end{array}$ & Australia & 12 weeks & $\begin{array}{l}1000 \mathrm{mg} / \text { day } \\
\text { or } 500 \mathrm{mg} / \text { day }\end{array}$ & $\begin{array}{l}\text { Non-specified } \\
\text { antidepressant } \\
\text { medication }\end{array}$ & Not described & $\begin{array}{c}\text { Improvements } \\
\text { in IDS-SR30 } \\
\text { and STAI total } \\
\text { scores after the } \\
\text { combination of } \\
\text { treatments. No } \\
\text { differences } \\
\text { between } \\
\text { different doses } \\
\text { of curcumin }\end{array}$ & $\begin{array}{l}\text { Minor severity } \\
\text { side effects }\end{array}$ \\
\hline & $\begin{array}{l}\text { NCT04744545 } \\
(2021)\end{array}$ & $\begin{array}{l}\text { Randomized, } \\
\text { placebo- } \\
\text { controlled } \\
\text { trial }\end{array}$ & - & 60 (estimated) & $\begin{array}{l}\text { MDD patients } \\
\text { (>18 years) }\end{array}$ & Canada & 12 weeks & $1500 \mathrm{mg} / \mathrm{Kg}$ & $\begin{array}{c}\text { Integrative } \\
\text { treatment } \\
\text { program based } \\
\text { on several } \\
\text { evidence- } \\
\text { based practices } \\
\text { and overseen } \\
\text { by licensed } \\
\text { clinical } \\
\text { therapists that } \\
\text { is delivered via } \\
\text { a Smartphone } \\
\text { app } \\
\end{array}$ & - & - & - \\
\hline $\begin{array}{l}\text { Obsessive } \\
\text { Compulsive } \\
\text { Disorder }\end{array}$ & $\begin{array}{l}\text { Moore and Nat } \\
\text { (2018) }\end{array}$ & Case report & - & 1 & $\begin{array}{l}\text { One case } \\
\text { report }\end{array}$ & United States & 3 weeks & $\begin{array}{c}90 \mathrm{mg} / \mathrm{day} \text { og } \\
\text { CUR; } 600-1800 \\
\text { mg/day of } \\
\text { NAC }\end{array}$ & Not specified & Not described & $\begin{array}{l}\text { Reduction in } \\
\text { CY-BOCS and } \\
\text { YGTSS total } \\
\text { scores }\end{array}$ & Not described \\
\hline
\end{tabular}


Table 2. Preclinical studies in neuropsychiatric diseases.

\begin{tabular}{|c|c|c|c|c|c|c|}
\hline Pathology & Reference & N Animals & Animal Model & Treatment & Biological Effects & Behavioral Effects \\
\hline \multirow[t]{2}{*}{ Schizophrenia } & Naserzadeh et al., (2018) & 24 (6/group) & $\begin{array}{c}\text { Ketamine-treated Wistar male } \\
\text { rats }\end{array}$ & $\begin{array}{c}\text { CUR-loaded magnetic } \\
\text { nanoparticles }(17 \mathrm{mg} / 300 \mathrm{ul} \\
\text { PBS), i.v. }\end{array}$ & $\begin{array}{l}\text { Reduction in MMP, ATP and } \\
\text { mitochondrial complex II } \\
\text { activity in mitochondria of the } \\
\text { cerebellum }\end{array}$ & $\begin{array}{l}\text { Reduction in the over-increased } \\
\text { locomotor activities } \\
\text { (side-to-side rocking and arcing } \\
\text { of neck) in the CUR-treated } \\
\text { ketamine rats, without reaching } \\
\text { the control values. }\end{array}$ \\
\hline & Moghaddam et al., (2021) & 35 (7/group) & $\begin{array}{l}\text { Ketamine-treated, during the } \\
\text { last } 15 \text { days of CUR } \\
\text { administration mice }\end{array}$ & $\begin{array}{c}\text { Curcumin-loaded } \\
\text { nanophytosomes }(20 \mathrm{mg} / \mathrm{kg}) \\
\text { during } 30 \text { days }\end{array}$ & $\begin{array}{l}\text { Reduction in biomarkers of } \\
\text { oxidative stress in cortical and } \\
\text { subcortical regions }\end{array}$ & $\begin{array}{l}\text { Reduction in anxiety in } \\
\text { CUR-treated ketamine mice. } \\
\text { Reduction in depressive-like } \\
\text { behaviors in ketamine mice } \\
\text { treated with CUR }\end{array}$ \\
\hline & Xu et al., 2005 & 72-84 (6-7/group) & OB male SP rats & $\begin{array}{c}1.25,2.5,5, \text { or } 10 \mathrm{mg} / \mathrm{Kg}, 14 \\
\text { days, p.o. }\end{array}$ & $\begin{array}{l}\text { Reversion of the deficits of } \\
\text { 5-HT and NA in hippocampus } \\
\text { and frontal cortex; 5-HIAA and } \\
\text { DOPAC in hippocampus and } \\
\text { DA in frontal cortex }\end{array}$ & $\begin{array}{l}\text { Improvement in forced } \\
\text { swimming, open field, and } \\
\text { passive avoidance tests }\end{array}$ \\
\hline & Xu et al., 2006 & 36 (6/group) & $\begin{array}{c}\text { Chronically stressed male SP } \\
\text { rats }\end{array}$ & $\begin{array}{c}2.5,5 \text {, or } 10 \mathrm{mg} / \mathrm{Kg} \text {, } 21 \text { days, } \\
\text { p.o. }\end{array}$ & $\begin{array}{l}\text { Reversed the effects on adrenal } \\
\text { gland size and weight. Blocked } \\
\text { the stress-induced decreases in } \\
\text { BDNF and pCREB/CREB }\end{array}$ & $\begin{array}{l}\text { High doses improved the } \\
\text { effects in shuttle-box test }\end{array}$ \\
\hline & Xu et al., 2007 & 30-35 (5-6/group) & $\begin{array}{l}\text { Chronically stressed male SP } \\
\text { rats }\end{array}$ & $\begin{array}{c}5,10, \text { or } 20 \mathrm{mg} / \mathrm{Kg}, 21 \text { days, } \\
\text { p.o. }\end{array}$ & $\begin{array}{l}\text { Improved hippocampal } \\
\text { neurogenesis and blocked the } \\
\text { decrease in 5-HT1A mRNA and } \\
\text { BDNF protein levels in the } \\
\text { hippocampal subfields }\end{array}$ & - \\
\hline & Kulkarni et al., 2008 & 30 (6/group) & $\begin{array}{l}\text { Reserpine treated male Laca } \\
\text { rats }\end{array}$ & $\begin{array}{l}10-80 \mathrm{mg} / \mathrm{Kg}, 60 \mathrm{~min} \text { before } \\
\text { tests, i.p. }\end{array}$ & $\begin{array}{c}\text { Increment of 5-HT, DA levels, } \\
\text { MAO-A and MAO-B at higher } \\
\text { doses }\end{array}$ & $\begin{array}{l}\text { Dose dependent improvement } \\
\text { in forced swimming test }\end{array}$ \\
\hline & Wang et al., 2008 & $40-48$ (10-12/group) & PCPA male ICR mice & $\begin{array}{c}2.5,5 \text {, or } 10 \mathrm{mg} / \mathrm{Kg}, 45 \mathrm{~min} \\
\text { before tests, p.o. }\end{array}$ & $\begin{array}{c}\text { Interaction with } 5-\mathrm{HT}_{1 \mathrm{~A} / 1 \mathrm{~B}} \text { and } \\
5-\mathrm{HT}_{2 \mathrm{C}} \text { receptors }\end{array}$ & $\begin{array}{l}\text { Improvement in forced } \\
\text { swimming test }\end{array}$ \\
\hline & Li et al., 2009 & 56 (7/group) & CUMS male Wistar rats & 15 or $30 \mathrm{mg} / \mathrm{Kg}$, 4 weeks, i.g. & $\begin{array}{l}\text { Reduced serum corticosterone } \\
\text { levels. Enhanced AC activity } \\
\text { and cAMP levels and } \\
\text { upregulated several AC } \\
\text { subtypes in the hippocampus, } \\
\text { cortex, and hypothalamus. } \\
\text { Increased 5-HT levels }\end{array}$ & $\begin{array}{l}\text { Improvement in sucrose } \\
\text { preference test }\end{array}$ \\
\hline & Bhutani et al., 2009 & 36 (6/group) & $\begin{array}{c}\text { Chronically stressed female } \\
\text { Wistar rats }\end{array}$ & 20 or $40 \mathrm{mg} / \mathrm{Kg}$, 21 days, i.p. & $\begin{array}{l}\text { Dose dependent reduction in } \\
\text { MAO-A and MAO-B. Reversed } \\
\text { the effects on NE, DA, and } \\
\text { 5-HT levels }\end{array}$ & $\begin{array}{l}\text { Dose dependent improvement } \\
\text { in forced swimming test }\end{array}$ \\
\hline
\end{tabular}


Table 2. Cont. Reference

N Animals

Animal Model

Treatment

Biological Effects

Behavioral Effects

Dose dependent reversion of $\mathrm{NE}, \mathrm{DA}$ and 5-HT reduced

Arora et al., 2011

48 (8/group)

Reserpine treated male Wista

100,200 , or $300 \mathrm{mg} / \mathrm{Kg}$, 2 days,

levels. Increment of SUB-P

concentration, nitrodative

stress, inflammatory cytokines,

NF- $K \beta$ and caspase- 3 levels hippocampus and cortex Sellitto and von-Frey hair tests. Improvement in forced swimming test

\begin{tabular}{|c|c|c|c|c|c|}
\hline \multicolumn{6}{|c|}{ hippocampus and cortex } \\
\hline Huang et al., 2011 & 18 (6/group) & CORT-treated male SP rats & 20 mg/Kg, 21 days, p.o. & $\begin{array}{l}\text { Increment of BDNF levels } \\
\text { induced by CORT treatment in } \\
\text { hippocampus and frontal } \\
\text { cortex }\end{array}$ & $\begin{array}{l}\text { Improvement in forced } \\
\text { swimming and sucrose } \\
\text { preference tests }\end{array}$ \\
\hline Kulkarni et al., 2011 & Not specified & Regular male Laca mice & $\begin{array}{l}50-200 \mathrm{mg} / \mathrm{Kg}, 30 \mathrm{~min} \text { before } \\
\text { tests, p.o. }\end{array}$ & $\begin{array}{l}\text { Increment of 5-HT at low doses } \\
\text { and DA at high doses }\end{array}$ & $\begin{array}{l}\text { Dose dependent improvement } \\
\text { in forced swimming test }\end{array}$ \\
\hline Zhang et al., 2012 & 60-75 (10-12/group) & SL327 male C57BL/6 mice & $40 \mathrm{mg} / \mathrm{Kg}$, 21 days, i.p. & $\begin{array}{c}\text { Improvement of ERK } \\
\text { deregulation on BDNF } \\
\text { expression in the amygdala }\end{array}$ & $\begin{array}{l}\text { Improvement in forced } \\
\text { swimming test }\end{array}$ \\
\hline Borre et al., 2013 & $40-48$ (10-12/group) & $\begin{array}{c}\mathrm{OB} \text { or } \mathrm{ZnSO} 4 \text { anosmia-induced } \\
\text { male SP rats }\end{array}$ & $\begin{array}{l}20 \mathrm{~g} / \text { day of } 0.25 \mathrm{mg} / \mathrm{Kg} \\
\text { curcumine diet, } 42 \text { days }\end{array}$ & $\begin{array}{l}\text { Reduced hippocampal atrophy } \\
\text { and decreased the peripheral } \\
\text { immune activation }\end{array}$ & $\begin{array}{l}\text { Attenuation of cognitive and } \\
\text { behavioral deficits in open field } \\
\text { tail suspension, passive } \\
\text { avoidance, T-maze and } \\
\text { holeboard tests }\end{array}$ \\
\hline Rinwa et al., 2013 & 50 (5/group) & OB male Wistar rats & $\begin{array}{c}\text { 100, 200, or } 400 \mathrm{mg} / \mathrm{Kg}, 2 \\
\text { weeks, p.o. }\end{array}$ & $\begin{array}{l}\text { Dose dependent reversion of } \\
\text { TNF- } \alpha \text {, caspase- } 3 \text { and BDNF } \\
\text { levels }\end{array}$ & $\begin{array}{l}\text { Dose dependent improvement } \\
\text { of forced swimming, sucrose } \\
\text { preference and open field tests }\end{array}$ \\
\hline Lin et al., 2013 & 40 (6-14/group) & CUS male SP rats & 40 mg $/ \mathrm{Kg}, 30$ days, p.o. & $\begin{array}{l}\text { Strong deactivation of the left } \\
\text { primary auditory cortex and } \\
\text { activation of the } \\
\text { amygdalohippocampal cortex }\end{array}$ & $\begin{array}{l}\text { Improvement in sucrose } \\
\text { preference and open field tests }\end{array}$ \\
\hline Hurley et al., 2013 & 32 (8/group) & Male Wistar Kyoto rats & $\begin{array}{c}50,100, \text { or } 200 \mathrm{mg} / \mathrm{Kg}, 10 \text { days, } \\
\text { i.p. }\end{array}$ & $\begin{array}{l}\text { Dose dependent increase in } \\
\text { hippocampal BDNF levels }\end{array}$ & $\begin{array}{c}\text { Improvement in forced } \\
\text { swimming test but no effects on } \\
\text { open field test }\end{array}$ \\
\hline Jiang et al., 2013 & 40 (10/group) & CMS male Wistar rats & $10 \mathrm{mg} / \mathrm{Kg}$, 3 weeks, i.g. & $\begin{array}{l}\text { Inhibited cytokine gene } \\
\text { expression at mRNA and } \\
\text { protein level and reduced the } \\
\text { activation of NF- } \kappa \beta\end{array}$ & $\begin{array}{l}\text { Reduced sucrose preference } \\
\text { and decreased locomotor } \\
\text { activity in open field test }\end{array}$ \\
\hline Zhang et al., 2013 & $40-48$ (10-12/group) & $\begin{array}{l}\text { NMDA receptor antagonists } \\
\text { treated male Kun-Ming mice }\end{array}$ & $\begin{array}{c}10,20 \text {, or } 40 \mathrm{mg} / \mathrm{Kg}, 45 \mathrm{~min} \\
\text { before tests, i.p. }\end{array}$ & $\begin{array}{c}\text { Interaction with } \\
\text { glutamate-NMDA-receptors }\end{array}$ & $\begin{array}{l}\text { Improvement in forced } \\
\text { swimming test }\end{array}$ \\
\hline Zhao et al., 2013 & 24-36 (8-12/group) & $\mathrm{CCI}$ in male ICR mice & $\begin{array}{c}5,15, \text { or } 45 \mathrm{mg} / \mathrm{Kg}, 3 \text { weeks, } \\
\text { p.o. }\end{array}$ & $\begin{array}{c}\text { Interaction with } 5-\mathrm{HT}_{1 \mathrm{~A}} \text { and } \\
\text { GABA receptors }\end{array}$ & $\begin{array}{l}\text { Dose dependent improvement } \\
\text { in forced swimming and tail } \\
\text { suspension tests }\end{array}$ \\
\hline
\end{tabular}

Depression 
Table 2. Cont.

\begin{tabular}{|c|c|c|c|c|c|c|}
\hline Pathology & Reference & N Animals & Animal Model & Treatment & Biological Effects & Behavioral Effects \\
\hline & Wang et al., 2014 & 40 (10/group) & $\begin{array}{l}\text { LPS treated male Kun-Ming } \\
\text { mice }\end{array}$ & $50 \mathrm{mg} / \mathrm{Kg}$, 7 days, i.p. & $\begin{array}{l}\text { Attenuated LPS induced } \\
\text { microglial activation and over } \\
\text { production of } \\
\text { pro-inflammatory cytokines, } \\
\text { levels of inductible nitric oxide } \\
\text { synthase and cyclooxygenase-2 } \\
\text { mRNA in the hippocampus } \\
\text { and prefrontal cortex }\end{array}$ & $\begin{array}{l}\text { Improvement in forced } \\
\text { swimming, tail suspension, and } \\
\text { sucrose preference tests }\end{array}$ \\
\hline & Liu et al., 2014 & 40 (10/group) & CUS male Wistar rats & $10 \mathrm{mg} / \mathrm{Kg}, 5$ weeks, i.g. & $\begin{array}{l}\text { Increased hippocampal BDNF } \\
\text { and ERK levels }\end{array}$ & $\begin{array}{l}\text { Reduced sucrose preference } \\
\text { and impaired learning and } \\
\text { memory function in open field } \\
\text { and Morris water maze tests }\end{array}$ \\
\hline & Cui et al., 2014 & 48 (8/group) & CUMS male SP rats & $\begin{array}{l}10,40 \text {, or } 80 \mathrm{mg} / \mathrm{Kg}, 30 \mathrm{~min} \\
\text { before tests, i.g. }\end{array}$ & $\begin{array}{l}\text { Improved the activity of } \\
\text { anti-oxidant enzymes and } \\
\text { energy metabolism enzymes }\end{array}$ & $\begin{array}{l}\text { Improvement in open field and } \\
\text { sucrose preference tests }\end{array}$ \\
\hline & Zhang et al., 2014 & 64 (16/group) & CUMS male Wistar rats & $40 \mathrm{mg} / \mathrm{Kg}$, 6 weeks, i.p. & $\begin{array}{l}\text { Reverted the effects on the } \\
\text { expression of BDNF, PSD-95 } \\
\text { and synaptophysin in the } \\
\text { lateral amygdala }\end{array}$ & $\begin{array}{l}\text { Improvement in open field, } \\
\text { forced swimming and sucrose } \\
\text { preference tests }\end{array}$ \\
\hline & Haider et al., 2015 & 24 (6/group) & Stressed male Wistar rats & 200 mg/Kg, 1 week, p.o. & $\begin{array}{l}\text { Improved the levels of MDA, } \\
\text { CAT, GPx, SOD and AChE }\end{array}$ & $\begin{array}{l}\text { Improvement in elevated plus } \\
\text { maze, open field and forced } \\
\text { swimming tests }\end{array}$ \\
\hline & He et al., 2016 & Not specified & $\begin{array}{l}\text { CORT-treated female C57BL/6 } \\
\text { mice }\end{array}$ & $20 \mathrm{mg} / \mathrm{Kg}$, 2 weeks, i.p. & $\begin{array}{l}\text { Improvement of DA levels in } \\
\text { blood. Increase in } \\
\text { neurotransmitters in } \\
\text { hippocampus and striatum. } \\
\text { Increased expression of CBR1, } \\
\text { p-MEK1, and p-ERK1/2 }\end{array}$ & $\begin{array}{l}\text { Improvement in forced } \\
\text { swimming and rotarod tests }\end{array}$ \\
\hline & Chang et al., 2016 & 30 (6/group) & OB male Wistar rats & $\begin{array}{c}10,20, \text { or } 40 \mathrm{mg} / \mathrm{Kg}, 45 \text { days, } \\
\text { p.o. }\end{array}$ & $\begin{array}{l}\text { Reversed the effects on NA, } \\
\text { 5-HT, 3, DOPAC acid and } \\
\text { 5-HIAA in the hippocampus. } \\
\text { Normalized the levels of DA, } \\
\text { NA and } \\
\text { 5-hydroxyindoleaceticacid in } \\
\text { the prefrontal cortex }\end{array}$ & $\begin{array}{l}\text { Improvement in passive } \\
\text { avoidance and open field tests }\end{array}$ \\
\hline & Yusuf et al., 2016 & 42 (6/group) & Stressed albino mice & $\begin{array}{c}2.5,5,10 \text {, or } 20 \mathrm{mg} / \mathrm{Kg}, 60 \mathrm{~min} \\
\text { before tests, i.p. }\end{array}$ & $\begin{array}{l}\text { Increase in SOD catalase } \\
\text { activity }\end{array}$ & $\begin{array}{l}\text { Improvement in force despair, } \\
\text { forced swimming and tail } \\
\text { suspension tests }\end{array}$ \\
\hline & Demir et al., 2016 & 34 (7-10/group) & $\begin{array}{l}\text { Cisplatin treated male Wistar } \\
\text { rats }\end{array}$ & 300 mg/Kg, 5 weeks, p.o. & - & $\begin{array}{l}\text { Improvement in forced } \\
\text { swimming, open field and } \\
\text { elevated plus maze tests }\end{array}$ \\
\hline
\end{tabular}


Table 2. Cont.

\begin{tabular}{|c|c|c|c|c|c|c|}
\hline Pathology & Reference & N Animals & Animal Model & Treatment & Biological Effects & Behavioral Effects \\
\hline & Shen et al., 2017 & 48 (6/group) & CMS male SP rats & $\begin{array}{c}15,30, \text { or } 60 \mathrm{mg} / \mathrm{Kg}, 33 \text { days, } \\
\text { p.o. }\end{array}$ & $\begin{array}{l}\text { Upregulation of IRS-1, Akt in } \\
\text { the liver and reversed } \\
\text { metabolic abnormalities }\end{array}$ & $\begin{array}{l}\text { Improvement in glucose } \\
\text { preference test }\end{array}$ \\
\hline & Yohn et al., 2017 & 45 (9/group) & $\begin{array}{l}\text { Tetrabenzamine treated male } \\
\text { SP rats }\end{array}$ & $\begin{array}{c}80-160 \mathrm{mg} / \mathrm{Kg} \text {, p.o. or } 2-8 \\
\mathrm{ul} / \mathrm{Kg} \text { infusions into ventricles }\end{array}$ & - & $\begin{array}{c}\text { Attenuated the effort-related } \\
\text { abnormalities in a choice } \\
\text { procedure test }\end{array}$ \\
\hline & He et al., 2017 & Not specified & $\begin{array}{l}\text { CORT administration in } \\
\text { C57BL/ } 6 \text { mice }\end{array}$ & $20 \mathrm{mg} / \mathrm{Kg}, 3$ weeks & $\begin{array}{l}\text { Increased DA/5-HT levels, CB1 } \\
\text { mRNA levels and CB1, } \\
\text { p-MEK1, and p-ERK1/2 } \\
\text { protein expression levels in the } \\
\text { hippocampus and striatum. } \\
\text { Increment on CBR1 expression } \\
\text { and proliferation of astrocytes } \\
\text { in the hippocampus and } \\
\text { striatum }\end{array}$ & $\begin{array}{l}\text { Improvement in forced } \\
\text { swimming test }\end{array}$ \\
\hline & Choi et al., 2017 & 16 (4/group) & $\begin{array}{l}\text { Chronically stressed male SP } \\
\text { rats }\end{array}$ & 50 or 100 mg /Kg, 18 days, p.o. & $\begin{array}{l}\text { Rescued the attenuated BDNF } \\
\text { expression and inhibited the } \\
\text { enhancement of COX-2 } \\
\text { expression }\end{array}$ & $\begin{array}{l}\text { Improvement in forced } \\
\text { swimming test }\end{array}$ \\
\hline & Ceremuga et al., 2017 & 55 (11/group) & Flumazenil treated male SP rats & $\begin{array}{l}20 \mathrm{mg} / \mathrm{Kg}, 10 \mathrm{~min} \text { before tests, } \\
\text { i.p. }\end{array}$ & $\begin{array}{l}\text { No interaction between } \\
\text { curcumin and benzodiazepine } \\
\text { site of the GABAs receptor was } \\
\text { observed }\end{array}$ & $\begin{array}{l}\text { No effects on forced swimming, } \\
\text { open field and elevated plus } \\
\text { maze tests }\end{array}$ \\
\hline & Vasileva et al., 2018 & 48 (6-7/group) & $\begin{array}{l}\text { CMS-LPS treated male Wistar } \\
\text { rats }\end{array}$ & $20 \mathrm{mg} / \mathrm{Kg}$, 8 days, i.g. & $\begin{array}{l}\text { Reversion of the increase in } \\
\text { cytokine levels }\end{array}$ & $\begin{array}{l}\text { Improvement in open field and } \\
\text { water maze tests }\end{array}$ \\
\hline & Lee and Lee, 2018 & $42-49$ (6-7/group) & SPS male SP rats & $\begin{array}{c}20,50 \text {, or } 100 \mathrm{mg} / \mathrm{Kg}, 14 \text { days, } \\
\text { i.p. }\end{array}$ & $\begin{array}{l}\text { Recover of neurochemical } \\
\text { abnormalities and decreases of } \\
\text { 5-HT in the hippocampus, } \\
\text { amygdala, and striatum }\end{array}$ & $\begin{array}{l}\text { Improvement in elevated pluz } \\
\text { maze, fear conditioning and } \\
\text { open field tests }\end{array}$ \\
\hline & Fan et al., 2018 & 24 (8/group) & CUMS male Wistar rats & $40 \mathrm{mg} / \mathrm{Kg}$, 5 weeks, i.p. & $\begin{array}{l}\text { Repression of the inflammatory } \\
\text { response and neuronal } \\
\text { structural abnormalities } \\
\text { produced by CUMS }\end{array}$ & $\begin{array}{l}\text { Improvement in forced } \\
\text { swimming and sucrose } \\
\text { preference tests }\end{array}$ \\
\hline & Lian et al., 2018 & 36 (6/group) & Regular male ICR mice & $\begin{array}{l}2,5, \text { or } 10 \mathrm{mg} / \mathrm{Kg}, 1-24 \mathrm{hs} \\
\text { before tests, i.g. }\end{array}$ & $\begin{array}{c}\text { Activation of 5- } \\
\mathrm{HT}_{1 \mathrm{~A}} / \mathrm{cAMP} / \mathrm{PKA} / \mathrm{CREB} / \mathrm{BDNF}- \\
\text { signaling } \\
\text { pathway }\end{array}$ & $\begin{array}{l}\text { Improvement in forced } \\
\text { swimming and tail suspension } \\
\text { tests. No alteration in open } \\
\text { field test }\end{array}$ \\
\hline & Fidelis et al., 2018 & $35-40$ (7-8/group) & $\begin{array}{l}\beta \text {-amyloid treated Swiss male } \\
\text { mice }\end{array}$ & $10 \mathrm{mg} / \mathrm{mL}, 12$ days, i.g. & $\begin{array}{l}\text { Reduced A } \beta \text {-oxidative stress } \\
\text { via SOD and CAT in the } \\
\text { prefrontal cortex }\end{array}$ & $\begin{array}{c}\text { Improvement in forced } \\
\text { swimming and tail suspension } \\
\text { tests. No changes in open field } \\
\text { test }\end{array}$ \\
\hline
\end{tabular}


Table 2. Cont.

\begin{tabular}{|c|c|c|c|c|c|c|}
\hline Pathology & Reference & N Animals & Animal Model & Treatment & Biological Effects & Behavioral Effects \\
\hline & Abd-Rabo et al., 2019 & 70 (14/group) & $\begin{array}{l}\text { Ovariectomized female Wistar } \\
\text { rats }\end{array}$ & 100 mg/Kg, 30 days, p.o. & $\begin{array}{l}\text { Improvement of serotonin } \\
\text { content by upregulating } \\
5-\mathrm{HT}_{1 \mathrm{~A}} \text { and down regulating } \\
\text { monoamine oxidase }\end{array}$ & $\begin{array}{l}\text { Improvement of forced } \\
\text { swimming test }\end{array}$ \\
\hline & Fan et al., 2019 & 72 (18/group) & CUMS male Wistar rats & 40 mg/Kg, 5 weeks, i.p. & $\begin{array}{l}\text { Reduced the expression of } \\
\text { IL-1 } \beta \text { and inhibited neuronal } \\
\text { apoptosis within neurons of the } \\
\text { ventromedial prefrontal cortex }\end{array}$ & $\begin{array}{l}\text { Improvement in forced } \\
\text { swimming and sucrose } \\
\text { preference tests }\end{array}$ \\
\hline & Mohammed et al., 2019 & 65 (11-15/group & $\begin{array}{l}\text { Reserpine treated male Wistar } \\
\text { rats }\end{array}$ & $20 \mathrm{mg} / \mathrm{Kg}, 7$ or 15 days, i.p. & $\begin{array}{c}\text { Restored DA and 5-HT levels, } \\
\text { but not NE levels after } 7 \text { days } \\
\text { of treatment. Increase in alpha } \\
\text { and beta } 2 \text {-waves, tetha and } \\
\text { beta } 1 \text {, and decrease in delta } \\
\text { waves }\end{array}$ & $\begin{array}{l}\text { Improvement in forced } \\
\text { swimming test }\end{array}$ \\
\hline & Madiha and Haider, 2019 & 30 (6/group) & Rotenone treated Wistar rats & $\begin{array}{l}100 \mathrm{mg} / \mathrm{Kg}, 2 \text { weeks, p.o., pre- } \\
\text { and post-Rotenone }\end{array}$ & $\begin{array}{l}\text { Reverted DA and 5-HT levels } \\
\text { in striatum and hippocampus }\end{array}$ & $\begin{array}{l}\text { Improvement in social } \\
\text { interaction and sucrose } \\
\text { preference test }\end{array}$ \\
\hline & Zhang et al., 2019 & 18-21 (6-7/group) & CUMS male SP rats & $100 \mathrm{mg} / \mathrm{Kg}, 4$ weeks, i.g. & $\begin{array}{l}\text { Reduced the expression of } \\
\text { IL-1 } 1 \beta, \text { IL- } 6 \text {, and TNF- } \alpha \text { and } \\
\text { suppressed activation of } \\
\text { NF- } \beta \beta \text {. Inhibited the P2 } \times \\
\text { 7R/NLRP3 inflammasome axis } \\
\text { activation, and reduced the } \\
\text { synthesis of IL-1 } 1 \beta \text {. } \\
\text { Ammeliorated the activation of } \\
\text { IDO and increased } \\
\text { kynurenine/tryptophan ratio }\end{array}$ & $\begin{array}{l}\text { Improvement in forced } \\
\text { swimming, elevated pluz maze } \\
\text { and sucrose preference tests }\end{array}$ \\
\hline & Liao et al., 2020 & 24 (8/group) & CUMS male SP rats & 100 mg/Kg, 4 weeks, i.g. & $\begin{array}{l}\text { Decrease in protein expression } \\
\text { of stress markers and increase } \\
\text { in CAT. Reversed the inhibition } \\
\text { of Nrf2-ARE signaling pathway } \\
\text { and increased mRNA } \\
\text { expression of NQO-1 and HO-1. } \\
\text { Increased the ratio } \\
\text { ofpCREB/CREB and BDNF, } \\
\text { PSD-95 and synaptophysin }\end{array}$ & $\begin{array}{l}\text { Improvement in forced } \\
\text { swimming, open field, } \\
\text { novelty-suppressed feeding, } \\
\text { and sucrose preference tests }\end{array}$ \\
\hline & Qi et al., 2020 & 35 (6/group) & $\begin{array}{l}\text { Reserpine treated male ICR } \\
\text { mice }\end{array}$ & $\begin{array}{l}5 \mathrm{mg} / \mathrm{Kg} \text {, i.g. or } 14.6,29.2,58.4 \\
\mathrm{ug} / \mathrm{Kg} \text {, nasal, } 1 \mathrm{~h} \text { before tests }\end{array}$ & $\begin{array}{l}\text { Increase in NE, DA, 5-HT and } \\
\text { their metabolites in } \\
\text { hippocampus and striatum }\end{array}$ & $\begin{array}{l}\text { Improvement in forced } \\
\text { swimming and tail suspension } \\
\text { tests }\end{array}$ \\
\hline & Wang et al., 2020 & 18 (6/group) & MCAO and CMS male SP rats & $100 \mathrm{mg} / \mathrm{Kg}$, 4 weeks, i.g. & $\begin{array}{l}\text { Blocked } \mathrm{Ca}^{+2} \text { accumulation, } \\
\text { inhibited the activation } \mathrm{Ca}^{+2} \\
\text { channels }\end{array}$ & $\begin{array}{l}\text { Improvement in forced } \\
\text { swimming and sucrose } \\
\text { preference tests }\end{array}$ \\
\hline & Li et al., 2020 & 50 (10/group) & Regular male ICR mice & 1,3 , or $9 \mathrm{mg} / \mathrm{Kg}, 3$ days, i.g. & $\begin{array}{l}\text { Modulated 5-HT } \mathrm{HA}_{1 \mathrm{~A}} \text {-dependent } \\
\text { cAMP/PKA / pCREB/BDNF } \\
\text { signaling pathway }\end{array}$ & $\begin{array}{l}\text { Improvement in forced } \\
\text { swimming and tail suspension } \\
\text { tests in a dose dependent } \\
\text { manner }\end{array}$ \\
\hline
\end{tabular}


Table 2. Cont.

\begin{tabular}{|c|c|c|c|c|c|c|}
\hline Pathology & Reference & N Animals & Animal Model & Treatment & Biological Effects & Behavioral Effects \\
\hline & Abu-Taweel and Al-Fifi, 2020 & 60 (6/group) & $\begin{array}{l}\text { Mercury chloride treated male } \\
\text { Swiss mice }\end{array}$ & 150 or 300 ppm, 36 days, p.o. & $\begin{array}{l}\text { Dose dependent improvements } \\
\text { of corticosterol and cortisone } \\
\text { levels in plasma }\end{array}$ & $\begin{array}{l}\text { Dose dependent improvements } \\
\text { in forced swimming, tail } \\
\text { suspension, open field and plus } \\
\text { maze tests }\end{array}$ \\
\hline & He et al., 2020 & 24 (3/group) & $\begin{array}{c}\text { CORT treated CBR1+/+ and } \\
\text { CBR1-/-mice }\end{array}$ & $20 \mathrm{mg} / \mathrm{Kg}$, 2 weeks, i.p. & $\begin{array}{l}\text { Increased mRNA and protein } \\
\text { expression levels of neuronal } \\
\text { markers, MEK and Tuj1. } \\
\text { Increase in released DA and NE } \\
\text { and the mRNA expression of } \\
\text { CBR1 and the downstream of } \\
\text { genes Rasgef1c and Egr1 }\end{array}$ & $\begin{array}{l}\text { Improvement in forced } \\
\text { swimming test }\end{array}$ \\
\hline & Zhang et al., 2020 & 24-27 (8-9/group) & $\mathrm{TN}$ male SD rats & $\begin{array}{c}45 \mathrm{mg} / \mathrm{Kg} \text {, } 27 \text { alternative days, } \\
\text { i.g. }\end{array}$ & $\begin{array}{c}\text { Altered ether lipid metabolism } \\
\text { and glycerophospholipid } \\
\text { metabolism }\end{array}$ & $\begin{array}{l}\text { Improvement in forced } \\
\text { swimming and sucrose } \\
\text { preference tests }\end{array}$ \\
\hline & Da Silva-Marques et al., 2020 & 40-52 (10-13/group) & CUMS male Swiss mice & 50 mg/Kg, 28 days, p.o. & $\begin{array}{l}\text { Increase in CAT levels in the } \\
\text { brain. No potential renal and } \\
\text { hepatic damage }\end{array}$ & $\begin{array}{l}\text { Improvement in forced } \\
\text { swimming and elevated plus } \\
\text { maze tests }\end{array}$ \\
\hline & Saied et al., 2021 & 50 (7-10/group) & OVX female albino rats & $100 \mathrm{mg} / \mathrm{Kg}$, 30 days, p.o. & $\begin{array}{l}\text { Modulated DA and NE levels, } \\
\text { downregulated MAO-B and } \\
\text { upregulated tyrosine } \\
\text { hydroxylase and DA receptors } \\
\text { in the limbic region. Reduced } \\
\text { the production of } \\
\text { corticosterone, IL-1 } \beta \text {, IL-6, and } \\
\text { nitric oxide. Normalized the } \\
\text { levels of MDA }\end{array}$ & $\begin{array}{l}\text { Improvement in the open field } \\
\text { test }\end{array}$ \\
\hline & Afzal et al., 2021 & 24 (8/group) & CRS male Wistar rats & $200 \mathrm{mg} / \mathrm{Kg}$, 1 week & $\begin{array}{c}\text { Reverted the effects on } \\
\text { hippocampal BDNF, 5-HT, DA, } \\
\text { and Ach levels }\end{array}$ & $\begin{array}{l}\text { Improvement in Morris water } \\
\text { maze and pattern separation } \\
\text { tests }\end{array}$ \\
\hline & Rubab et al., 2021 & 40 (5/group) & $\begin{array}{l}\text { LPS administration in male SP } \\
\text { rats }\end{array}$ & $40 \mathrm{mg} / \mathrm{Kg}$, 8 days, i.p. & $\begin{array}{l}\text { Suppressed the expression of } \\
\text { BDNF, TNF- } \alpha, \text { p-NF- } k \beta \text {, and } \\
\text { COX- } 2\end{array}$ & $\begin{array}{l}\text { Improvement in forced } \\
\text { swimming, tail suspension, } \\
\text { elevated plus maze, and } \\
\text { light-dark box tests }\end{array}$ \\
\hline & Pan et al., 2021 & 45 (9/group) & Regular ICR male mice & $10 \mathrm{mg} / \mathrm{Kg}, 3$ days, p.o. & $\begin{array}{c}\text { Increased levels of 5-HT and } \\
\text { NA in the hippocampus and } \\
\text { frontal cortex. Inhibition of } \\
\text { MAO-A activity }\end{array}$ & $\begin{array}{l}\text { Improvement in forced } \\
\text { swimming, tail suspension } \\
\text { tests. No effects on sucrose } \\
\text { preference and novelty } \\
\text { suppressed feeding tests }\end{array}$ \\
\hline & Khadrawy et al., 2021 & 21 (7/group) & $\begin{array}{l}\text { Reserpine treated male Wistar } \\
\text { rats }\end{array}$ & $5 \mathrm{mg} / \mathrm{Kg}$, 14 days, i.p. & $\begin{array}{l}\text { Reversion of the levels of MAO, } \\
\text { AchE, } \mathrm{Na}^{+}, \mathrm{K}^{+} \text {, and ATPase }\end{array}$ & $\begin{array}{l}\text { Improvement in forced } \\
\text { swimming test }\end{array}$ \\
\hline
\end{tabular}


Table 2. Cont.

\begin{tabular}{|c|c|c|c|c|c|c|}
\hline Pathology & Reference & N Animals & Animal Model & Treatment & Biological Effects & Behavioral Effects \\
\hline \multirow{4}{*}{ Autism } & Bhandari and Kuhad, 2015 & 40 (5/group) & $\begin{array}{l}\text { Intracerebroventricular } \\
\text { injection of PPA in male SP rats }\end{array}$ & $\begin{array}{l}50,100 \text {, or } 200 \mathrm{mg} / \mathrm{kg} / \text { day, } \\
\text { during } 4 \text { weeks, p.o. }\end{array}$ & $\begin{array}{l}\text { Reduction in the (TBARS) in } \\
\text { CUR animals. Increase in } \\
\text { glutathione, superoxide } \\
\text { dismutase and catalase levels } \\
\text { in CUR rats' brains. Restoration } \\
\text { of mitochondrial enzyme } \\
\text { complex I activities in CUR rats. } \\
\text { Dose-dependent reduction in } \\
\text { MMP-9 in PPA rats treated } \\
\text { with CUR }\end{array}$ & $\begin{array}{c}\text { Dose-dependent improvements } \\
\text { of social skills in CUR-treated } \\
\text { PPA animal. Improvement in } \\
\text { locomotor activity, rotarod, } \\
\text { elevated plus maze and open } \\
\text { field tests, especially at } 200 \\
\mathrm{mg} / \mathrm{kg} / \text { day. }\end{array}$ \\
\hline & Al-Askar et al., 2017 & 40(10/group) & $\begin{array}{l}\text { Fetal exposition (GD12.5) to } \\
\text { VPA in Wistar rats }\end{array}$ & $1 \mathrm{~mL}$, oral, for 7 days after birth & $\begin{array}{l}\text { Increase in brain and body } \\
\text { weight in CUR-treated VPA } \\
\text { animals. Depletion of IFN- } \gamma \text { in } \\
\text { VPA rats with curcumin } \\
\text { treatment. Partial restoration of } \\
\text { IL-6 and glutamate normal } \\
\text { levels in VPA rats with CUR }\end{array}$ & - \\
\hline & Zhong et al., 2020 & 48 (12/group) & BTBRT+ltpr3tf/J mice & $\begin{array}{l}20 \mathrm{mg} / \mathrm{kg} \text {, from PND } 6 \text { to PND } \\
\text { 8, i.p. }\end{array}$ & $\begin{array}{l}\text { Enhancement of neural stem } \\
\text { cell proliferation in BTBRT } \\
\text { mice treated with CUR }\end{array}$ & $\begin{array}{l}\text { Improvement in 3-chambered } \\
\text { social approach and novel } \\
\text { object recognition tests. No } \\
\text { effect of CUR in male-female } \\
\text { reciprocal social interaction. No } \\
\text { changes in anxiety nor } \\
\text { locomotor activity caused by } \\
\text { CUR }\end{array}$ \\
\hline & Jayaprakash et al., 2021 & 54 (7/group) & BTBRT+ltpr3tf/J mice & $\begin{array}{l}25,50 \text {, or } 100 \mathrm{mg} / \mathrm{kg}, 1 \text { week } \\
\text { before tests, i.p. }\end{array}$ & $\begin{array}{l}\text { Restoration of catalase and } \\
\text { superoxide dismutase in } \\
\text { hippocampus and cerebellum } \\
\text { of CUR-treated BTBRT mice }\end{array}$ & $\begin{array}{l}\text { Dose-dependent increase in } \\
\text { sociability in CUR-treated mice }\end{array}$ \\
\hline \multirow[b]{2}{*}{$\begin{array}{l}\text { Obsessive Compulsive } \\
\text { Disorder }\end{array}$} & Jithendra and Murthy, 2010 & 30 (6/group) & Quinpirol treated Wistar rats & 5 or $10 \mathrm{mg} / \mathrm{Kg}, 35$ days, p.o. & Increased 5-HT and DA levels & $\begin{array}{c}\text { Improvement in open field and } \\
\text { water maze tests }\end{array}$ \\
\hline & Mishra et al., 2021 & 42 (6/group) & Male Swiss mice & $10,15,25$, or $40 \mathrm{mg} / \mathrm{Kg}$, i.p. & - & $\begin{array}{l}\text { Dose dependent improvement } \\
\text { in marble-burying behavior. } \\
\text { No effects in motor activity }\end{array}$ \\
\hline
\end{tabular}




\section{Results}

\subsection{Schizophrenia}

Current therapies for schizophrenia mostly focus on treatment with antipsychotics, the prolonged use of which is prone to cause severe extrapyramidal side effects, such as parkinsonism or tardive dyskinesia [27]. In addition, long-term administration of typical antipsychotics decreases antioxidant enzyme levels, thus perhaps participating in the exacerbation of oxidative events [28]. Therefore, the search for new approaches is of great importance. In this regard, the likely involvement of oxidative stress and inflammation in the pathophysiology of schizophrenia has supported the use of curcumin in various preclinical and clinical studies.

On the preclinical side, we only found two studies. In the first one, curcumin-loaded nanoparticles ( $30 \mathrm{mg} / \mathrm{kg}$, i.p.) were administered to ketamine-treated rats, achieving a reduction in metalloproteases (MMP), adenosine triphosphate (ATP), and mitochondrial enzyme complex II activity in cerebellar mitochondria, along with a reduction in the overincreased locomotor activities in the side-to-side rocking and neck arcing tests [29]. In the second one, published in 2021, the administration of curcumin ( $30 \mathrm{mg} / \mathrm{kg}$, i.p.) to ketamine-treated mice induced a reduction in oxidative stress biomarkers in the brain, and a reduction in anxiety and depression-like behaviors [30].

On the clinical arena, five studies and trials have been conducted. The first one is an OLS (NCT01875822) in which 17 schizophrenic patients received 1 or $4 \mathrm{~g}$ of curcumin or placebo for 16 weeks. However, to our knowledge, there are no published results to date. In 2017, the first randomized, double-blind, placebo-controlled study reporting the effects of curcumin on brain-derived neurotrophic factor (BDNF), a neurotrophin involved in neuroprotection, neuroregeneration and cell survival among other functions, and cognition in 36 patients with schizophrenia and inpatients was published [31]. Patients receiving curcumin ( $360 \mathrm{mg} /$ day for 8 weeks) showed an increased in BDNF levels relative to baseline and compared to placebo. However, the study failed to find any effect on cognition or other clinical symptoms. In contrast, the three most recent studies showed more promising results as an add-on to antipsychotics in the treatment of negative symptoms (NCT02298985, NCT02476708) or both positive and negative symptoms [32]. The first study, an 8-week randomized, double-blind, placebo-controlled, parallel, fixed-dose pilot clinical trial in 12 patients with schizophrenia, showed that $300 \mathrm{mg}$ of curcumin add-on to conventional medication significantly improved working memory and reduced interleukin-6 (IL-6) levels [33]. The second study, also a randomized, double-blind, placebo-controlled, addon clinical trial reported an improvement in negative symptoms in 20 patients receiving curcumin ( $3 \mathrm{~g} /$ day, for 24 weeks) compared to 18 patients receiving placebo [34]. Finally, in the third randomized, double-blind, placebo-controlled clinical trial, curcumin (160 $\mathrm{mg} /$ day, for 16 weeks) plus usual antipsychotic medication was administered to 28 patients with chronic schizophrenia (28 additional patients received a placebo). Curcumin-treated patients showed an improvement on the negative and positive subscales, the general psychopathology subscale, total Positive and Negative Syndrome Scale (PANSS), Clinical Global Impressions-Severity (CGI-S), and Clinical Global Impressions (CGI-I) scores in comparison with the control group [32].

Therefore, the schizophrenia picture shows an unbalanced proportion of preclinical and clinical studies, biased towards the clinical ones. In all cases, curcumin was welltolerated and, overall, an improvement of clinical symptoms was observed, especially in negative symptomatology. However, the heterogeneity of doses and curcumin formulations used precludes drawing more robust conclusions.

\subsection{Depression}

Pathophysiology and aetiology of major depression disorder (MDD) are heterogeneous, and traditional antidepressant treatments have some limitations in terms of efficacy, symptom improvement, and side effects. Although the pathological mechanisms are not fully understood, oxidative stress and inflammation seem to play an important role in 
the pathogenesis of depression, probably through increased inflammatory factors in the central nervous system. In this regard, curcumin has been used and demonstrated to be an effective adjuvant treatment for MDD in several studies.

On the preclinical side, we found a total of 57 studies, 19 of which were performed in mice and 38 in rats. The dose of curcumin ranged from 1 to $300 \mathrm{mg} / \mathrm{Kg}$. The duration of treatment varied from a single intake to a 5-week treatment with curcumin. Regarding the route of administration, 36 used oral administration ( 23 in the drinking water or food and 13 by gavage), 19 used intraperitoneal administration, and two of them reported no information on the route of administration. In addition, several models of MDD were used, most of them (21) based on a stress-induced model, such as Chronic Unpredictable Mild Stress (CUMS), Single Prolonged Stress (SPS), Chronic Unpredictable Stress (CUS), or Chronic Mild Stress (CMS), while eight of them were induced by surgery (olfactory bulbectomy, ovarectomy, chronic constriction injury or middle cerebral artery occlusion), nine were induced by the administration of reserpine or corticosterone (CORT), and the remaining 19 were induced by other models of MDD.

The antidepressant efficacy of curcumin in modulating depressive behavior in different animal models has been shown in a large number of behavioral studies. Most of the studies reported improved performance in the forced swimming test [35-48], increased locomotor activity in the open field test [49-64], decreased anxiety in the elevated plus maze test [57,59,64-66], improved anhedonia in the sucrose preference test [51,52,54,56,58,62,67-76], improved short and long-term memory in the passive avoidance test $[49,50,55]$ and water maze test $[54,60,77]$, reduced escape response in the shuttle-box test [78], attenuated the effort-related abnormalities in a choice procedure test [79], and reduced stress in the tail suspension test $[50,64,66,69,80-88]$. Only one study found no improvements in anxiety, as measured by the open field and elevated plus maze tests, nor in "depressive-like" states, as measured by the forced swimming test [89]. Another study found no improvements in anhedonia, as measured by the sucrose preference test [86].

The administration of curcumin has been shown to regulate serotonin (5-HT), dopamine (DA), and noradrenaline (NA) levels. Twenty studies reported an increment of 5-HT levels in the hippocampus, striatum or frontal cortex, which may be due to the interaction found between curcumin and 5-HT/cAMP/PKA/CREB/BDNF-signaling pathway or $5-\mathrm{HT}_{1 \mathrm{~A} / 1 \mathrm{~B}}$ and $5-\mathrm{HT}_{2 \mathrm{C}}$ receptors $[35,40,80,83,85,90]$. Besides, fifteen studies reported an increased level of DA $[38,41,42,44-46,48,49,55,72,77,81,87,91]$. NA was also incremented in five studies $[46,49,55,63,86]$. In addition, curcumin has been claimed to present beneficial effects on reducing inflammatory cytokines (IL-1 $\beta$, IL-6) $[60,63,69-71,76,77,91]$, reducing the NF-kB-iNOS-COX-2-TNF- $\alpha$ inflammatory signaling pathway $[39,51,52]$, and modulating the levels of antioxidant markers, such as monoamine oxidase (MAO), malondialdehyde (MDA), CAT, or SOD $[43,56,57,62,65,66,82,84,88]$. Furthermore, the BDNF is incremented by curcumin treatment $[36,39,47,51,54,58,66,67,77,78,90]$. Other effects of curcumin have been described in different animal models of depression, such as an interaction with glutamate N-Methyl-D-Aspartate (NMDA) receptors [37], an inhibition of $\mathrm{Ca}^{+2}$ channels [74], an increased level of corticosterol and cortisone in plasma [64], or an altered lipid metabolism [75], or an upregulation of the insulin receptor IRS-1 and protein kinase-B (PKB) in the liver [73]. In contrast, only one study reported no effects of curcumin, regarding its interaction with the benzodiazepine site on gamma-aminobutyric acid (GABA) receptor [89].

Only two neuroimaging studies have evaluated the effect of curcumin on brain morphometry and glucose metabolism in an animal model of depression, showing improvements such as a reduction in hippocampal atrophy [50] and an activation of the metabolism of the amygdala in a positron emission tomography (PET) imaging study after curcumin treatment [53].

In the clinical setting, one OLS and eight clinical trials were performed. In 2013, two trials were conducted, one in India (NCT01022632) [92] and one in Israel (NCT01750359) [93]. In the first one, a randomized, active controlled, parallel group trial, curcumin (1000 
$\mathrm{mg}$ /day) or fluoxetine ( $20 \mathrm{mg} /$ day) were administered to patients with MDD for 6 weeks (17 patients on fluoxetine alone, 16 patients on curcumin, and 18 patients on fluoxetine/curcumin), which showed no biological effects on depressive symptoms, as measured by the Hamilton Depression Rating Scale (HDRS). In the second study, a randomized, double-blind, placebo-controlled, pilot clinical trial, curcumin (1000 mg/day, for 8 weeks) was administered to 19 patients (27 patients on placebo), showing no improvement in the MDD symptoms measured by the HDRS and the Montgomery-Asberg Depression Rating (MADRS) scales.

In contrast, the remaining trials conducted from 2014 until now showed better results. In 2014, two randomized, double-blind, placebo-controlled trials were conducted in Australia in 25 patients with MDD receiving curcumin (1000 mg/day, for 8 weeks) and 25-27 patients receiving placebo $[94,95]$. Both studies showed an improvement in MDD symptomatology (IDS-SR30 total score), and the second one also found an increase in some depression-related biomarkers, such as urinary Thromboxane B2 (TBX-B2) and substance-P (SUB-P), and plasma endothelin-1 (ET-1) and leptin levels. Thus, higher levels of these biomarkers were associated with greater reductions in IDS-S30 total scores.

In 2015, one OLS in Iran [96] and a randomized, double-blind, placebo-controlled trial in China were conducted [97]. In the first study, curcumin (1000 mg/day, for 6 weeks) was administered to 61 patients with MDD (50 patients on placebo), showing a decrease in anxiety levels as measured by the Hospital Anxiety and Depression Scale (HADS) and reductions in MDD symptomatology as measured by the Beck Depression Inventory II (BDI-II) scale [96]. Of note, piperine (10 $\mathrm{mg} /$ day) was used to increase the bioavailability of curcumin. In the second trial, curcumin (1000 mg/day, for 6 weeks) was administered to 50 patients with MDD (50 patients on placebo), showing an improvement in the HDRS and MADRS scales [97].

In 2017, another randomized, double-blind, placebo-controlled clinical trial was conducted in Australia [98]. The effects of two different doses of curcumin $(500 \mathrm{mg} /$ day or $1000 \mathrm{mg}$ /day, for 12 weeks) was evaluated in 28 and 33 patients with MDD, respectively. Both doses induced improvements in symptomatology and anxiety measured by IDS-SR30 and State-Trait Anxiety Inventory (STAI) scales, with no difference between the doses used. In 2018, a randomized, double-blind, placebo controlled trial was performed in 30 patients with MDD treated with an increasing dose of curcumin (500 mg/day to $1500 \mathrm{mg} /$ day with increments of $250 \mathrm{mg}$ /week, for 12 weeks) and 31 on placebo [99]. This escalating medication dosage induced an improvement in the severity of depression on the MADRS scale. Despite this behavioral improvement, no significant effects were found in blood chemistry and electrocardiogram measurements.

Finally, a randomized, placebo-controlled trial is currently in the recruiting phase (NCT04744545 2021). The study estimates to recruit 60 patients with MDD, with curcumin (1500 mg/day) as an adjuvant treatment for MDD.

\subsection{Autism Spectrum Disorder (ASD)}

Although the etiology of this disorder is largely unknown, oxidative stress and inflammation have been hypothesized to be key factors in its occurrence, especially through an exacerbated increase in pro-inflammatory metalloproteases. In this sense, the antiinflammatory and antioxidant potential of curcumin could be effective in alleviating this disorder.

So far, no clinical trials have been conducted in patients with ASD. On the preclinical field, only four studies have been performed in animal models, two in rats and two in mice. The first study used a model based on the intracerebroventricular injection of propanoic acid (PPA) in Sprague-Dawley rats. After the PPA injection, curcumin was orally administered for 4 weeks at different doses $(50 / 100 / 200 \mathrm{mg} / \mathrm{kg})$. The treatment restored many behavioral defects in PPA rats, such as social interaction, anxiety, depression, and repetitive behaviors. In addition, curcumin reduced the levels of MMP-9 and Thiobarbituric Acid Reactive Substances (TBARs), increased the activity of GSH, CAT, and SOD, and 
restored normal function of mitochondrial enzyme complex 1 [100]. In 2017, another study, based on prenatal valproic acid (VPA) exposure to fetal Wistar rats, proposed early postnatal administration of curcumin (first seven days after birth). This approach was reported to restore oxidative stress deficits and the abnormal body and brain weight values [101]. Two subsequent studies were performed in the BTBRT ${ }^{+} 1 \mathrm{tpr} 3^{\text {tf }} / \mathrm{J}$ (BTBRT) mouse model. The first one, in which curcumin $(20 \mathrm{mg} / \mathrm{kg})$ was administered from PND 6 to 8 , reported enhanced neural stem cell proliferation, along with increased sociability and improved short-term memory [102]. The second study evaluated three different doses of curcumin $(25 / 50 / 100 \mathrm{mg} / \mathrm{kg})$, showing restoration of different oxidative stress markers in the hippocampus and cerebellum, along with a dose-dependent increase in sociability in curcumin-treated mice [103].

Taken together, these results suggest that curcumin could be effective in preventing some autistic behavioral and biochemical traits, but the lack of clinical trials do not allow for drawing solid conclusions.

\subsection{Obsessive Compulsive Disorder (OCD)}

The etiology of OCD is not fully understood either, but it has been hypothesized that it is a result of the existence of a deficit of monoamines in specific brain regions such as the orbitofrontal cortex and the anterior cingulate gyrus. In this regard, the potential of curcumin as an inhibitor of MAO-A and MAO-B, both of which are involved in monoamines degradation [97], led researchers to test its efficacy as an adjuvant treatment in this disorder.

Only two preclinical studies have been conducted to date. The first, carried out in 2010 by Jithendra and Murthy, evaluated the potential of orally administered curcumin (5 or $10 \mathrm{mg} / \mathrm{kg}$ ) as a therapeutic approach to reduce obsessive-compulsive signs in the quinpirole-induced OCD rat model. Following treatment with both doses, a reduction in brain DA levels, together with an increase in serotonin levels, was observed in curcumintreated pathological rats. In addition, an improvement in obsessive-compulsive symptoms together with a protective effect on the water maze memory task at both doses was reported [97]. The second study was recently conducted, in 2021, by Mishra et al. In this work, they intraperitoneally administered ethanolic extract of curcumin $(10,15,25$, or $40 \mathrm{mg} / \mathrm{kg}$ ) to Swiss albino mice that had poor performance in the marble-burying behavior (MBB) and motor activity (MA) tests. The treatment at the dose of $40 \mathrm{mg} / \mathrm{kg}$ resulted in improved performance in the MBB test, but not in the MA [98].

From a clinical point of view, no OLS or trials have been conducted to date. However, a case report was announced in 2018. In this case, a 3-year-old child with a diagnosis of OCD and tics was treated with a combination of $\mathrm{N}$-acetylcysteine (dose increase from 600 to 1800 $\mathrm{mg}$ /day) and curcumin ( $90 \mathrm{mg} /$ day). After 7 days, a complete remission of tics and OCD symptoms was observed. Finally, after 3 weeks, symptoms remitted completely, together with a drastic reduction in Children's Yale-Brown Obsessive Compulsive (CY-BOCS) and Yale Global Tic Severity (YGTSS) total scores [99].

Taken together, these data do not shed enough light to conclude whether curcumin is an effective compound for the treatment of OCD, especially in the case report, in which the observed positive effect could also be attributed to the administration of NAC.

\section{Discussion}

Anti-inflammatory, antioxidant, and neuroprotective properties of curcumin, along with many multi-target beneficial effects, such as the modulation of monoamine synthesis, have exponentially promoted the investigation of its properties during this last decade. Two-hundred and ninty-six articles containing research on curcumin were published in the PubMed database in 2005. In 2010, this number increased to 714 and, in 2020, to 2130. The field of psychiatry has not been immune to this boost. The likely involvement of oxidative stress, inflammation, and monoamine deficits in the pathophysiology of many psychiatric disorders, together with the poor response to current therapies in a significant proportion of these patients, have pushed researchers to investigate new therapeutic compounds that 
could improve current treatments. In this work, we reviewed the literature on the effects and efficacy of curcumin and its derivatives in four psychiatric disorders: schizophrenia, depression, autism, and obsessive-compulsive disorder (OCD). A total of 65 preclinical studies and 14 clinical trials were reported. Most of these studies were conducted on depression, approximately $88 \%$ were preclinical studies and $64 \%$ were clinical studies. In all disorders, curcumin was well tolerated, with no harmful side effects. This was not surprising, as curcumin has been used for the last centuries as an additive spice in East Asian cuisine. Moreover, curcumin was shown to be beneficial in palliating or reversing symptoms associated with psychiatry in all the studies analyzed and completed, with the exception of one preclinical and two clinical studies in depression, which reported no improvement [89,92].

As mentioned above, the percentage of studies on depression, as compared to autism and OCD, is highly unbalanced. This fact (no clinical trial on the effect of curcumin on either autism or OCD has been conducted so far) prevents us from drawing solid conclusions on the possible effectiveness of curcumin in these disorders. This large bias towards studies on depression could be explained by a likely predisposition of patients with depression to use new therapies compared to psychotic or autistic patients. Nevertheless, we believe that the efforts directed to the synthesis of new formulations of this compound, together with an improvement of its pharmacokinetic properties, will increase the interest in curcumin and decrease the reluctance to use it in more psychiatric disorders, such as OCD or autism.

In the case of schizophrenia, the reported outcomes showed a beneficial effect of curcumin in both preclinical and clinical studies. In clinical trials, curcumin proved to be effective in alleviating both positive and negative symptoms of schizophrenia when administered together with regular antipsychotic medication. The clinical relevance of these results could be of great importance, due to the adverse events that can be caused by the extensive and chronic use of antipsychotics. Besides, its excessive use can lead to a paradoxical increase in oxidative stress and inflammation. In addition, some widely used antipsychotics, such as clozapine, are able to activate hepatic sterol regulatory elementbinding proteins (SREBPs) and enhance downstream lipogenesis, leading to an increase in lipid peroxides and brain phospholipase A2 (PLA $)$, which can lead to cell death [104]. In this sense, curcumin could exert its beneficial effect in schizophrenia through an inhibition of PLA $_{2}$ enzyme [105]. Nevertheless, the heterogeneity of the protocols used in these studies, in terms of curcumin doses and stage of the disorder, makes it difficult to make comparisons between trials and draw a solid conclusion.

In depression, we found the vast majority of studies, in both preclinical and clinical domains, showed some beneficial effect of curcumin in reducing symptoms associated with depression. In addition to the recognized role of curcumin as an anti-inflammatory and antioxidant agent, positive improvement of depressive deficits could be exerted through modulation of the indolamine 2,3-dioxygenase (IDO) enzyme, involved in the kynurenine pathways and, thus, in the inhibition of serotonin synthesis. Curcumin treatment was shown to be able to counteract the action of this enzyme $[76,106]$. Therefore, the overall effect of curcumin in this disorder seems to be mainly positive.

Even though the results we have found and show here are overwhelmingly positive, there is a significant amount of literature warning about this compound, especially concerned about its poor pharmacokinetics and chemical instability, and its non-specific multi-target effects $[17,18]$. Although the results presented in this review pointed in a different direction, we considered it relevant to mention, at least, these discordant voices which claim that curcumin is an unstable compound with barely therapeutic efficacy.

Finally, even though this review provides a thorough review of the current literature, there are several limitations. First and foremost, the great heterogeneity of methodologies used in all the studies has hindered the possibility of making comparisons between studies. This has been especially relevant in the case of the different formulations of curcumin and the doses used. Secondly, the small number of trials and clinical studies carried out in some of the pathologies mentioned, together with the small number of participants in 
some of them, prevents us from drawing solid conclusions. Thirdly, the small number of trials in some cases forced us to compare trials of the same disease but focused on different stages of the disease or on adjuvant treatments. Although this work was conducted after an exhaustive search in well-known databases, there is always an intrinsic limitation derived from the non-systematic nature of this review. One final remark derives from the wellknown problem of publication bias towards positive results, which may prevent some negative-result studies from being reported in high impact journals, or even published at all.

\section{Conclusions}

Overall, curcumin, due to its anti-inflammatory and antioxidant properties, has been shown to be effective in the vast majority of the studies presented. However, the lack of homogeneity of the protocols used and the scarce number of trials prevents us from concluding whether curcumin is really a useful therapeutic tool in the psychiatric field.

Author Contributions: N.L.-R. and D.R.-M. contributed equally to this work. N.L.-R.: Conceptualization, methodology, writing—original draft preparation, writing—review and editing. D.R.-M.: Conceptualization, methodology, writing — original draft preparation, writing —review and editing. M.D.: review and editing, funding acquisition. M.L.S.-M.: conceptualization, methodology, writingoriginal draft preparation, writing - review and editing, project administration, funding acquisition. All authors have read and agreed to the published version of the manuscript.

Funding: M.L.S.-M. was supported by the Ministerio de Ciencia, Innovación y Universidades, Instituto de Salud Carlos III (project number PI17/01766, and grant number BA21/00030), co-financed by the European Regional Development Fund (ERDF), "A way to make Europe", CIBER de Salud Mental (project number CB07/09/0031), Delegación del Gobierno para el Plan Nacional sobre Drogas (project number 2017/085); and Fundación Alicia Koplowitz (FAK16/01). D.R.-M. was supported by Consejería de Educación e investigación, Comunidad de Madrid, co-funded by the European Social Fund "Investing in your future" (grant, PEJD-2018-PRE/BMD-7899). N.L.-R. was supported by the Instituto de investigación Sanitaria Gregorio Marañón, “Programa Intramural de Impulso a la I+D+I 2019". The CNIC is supported by the Instituto de Salud Carlos III (ISCIII), the Ministerio de Ciencia e Innovación (MCIN) and the Pro CNIC Foundation, and is a Severo Ochoa Center of Excellence (SEV-2015-0505).

Data Availability Statement: Not applicable.

Conflicts of Interest: The authors declare no conflict of interest.

$\begin{array}{ll}\text { Abbreviations } \\ \text { AchE } & \text { Acetylcholinesterase } \\ \text { ATP } & \text { Adenosine triphosphate } \\ \text { ASD } & \text { Autism spectrum disorders } \\ \text { Bcl } & \text { B-cell lympho MAO } \\ \text { BDI-II } & \text { Beck Depression Inventory II } \\ \text { BDNF } & \text { Brain-derived neurotrophic factor } \\ \text { BLYS } & \text { B lymphocyte stimulator } \\ \text { BZDs } & \text { Benzodiazepines } \\ \text { Ca } & \text { Calcium } \\ \text { cAMP } & \text { cyclic adenosine monophosphate } \\ \text { CAT } & \text { Catalase } \\ \text { CBR } & \text { Cannabinoid receptor } \\ \text { CCI } & \text { Chronic constriction injury } \\ \text { CDSS } & \text { Clinical depression screening scale } \\ \text { CGI-I } & \text { Clinical global impressions-improvement } \\ \text { CGI-S } & \text { Clinical global impressions-severity } \\ \text { CMS } & \text { Chronic mild stress } \\ \text { COX-2 } & \text { Cyclooxygenase-2 } \\ \text { CUMS } & \text { Chronic unpredictable mild stress } \\ \text { CORT } & \text { Corticosterone }\end{array}$




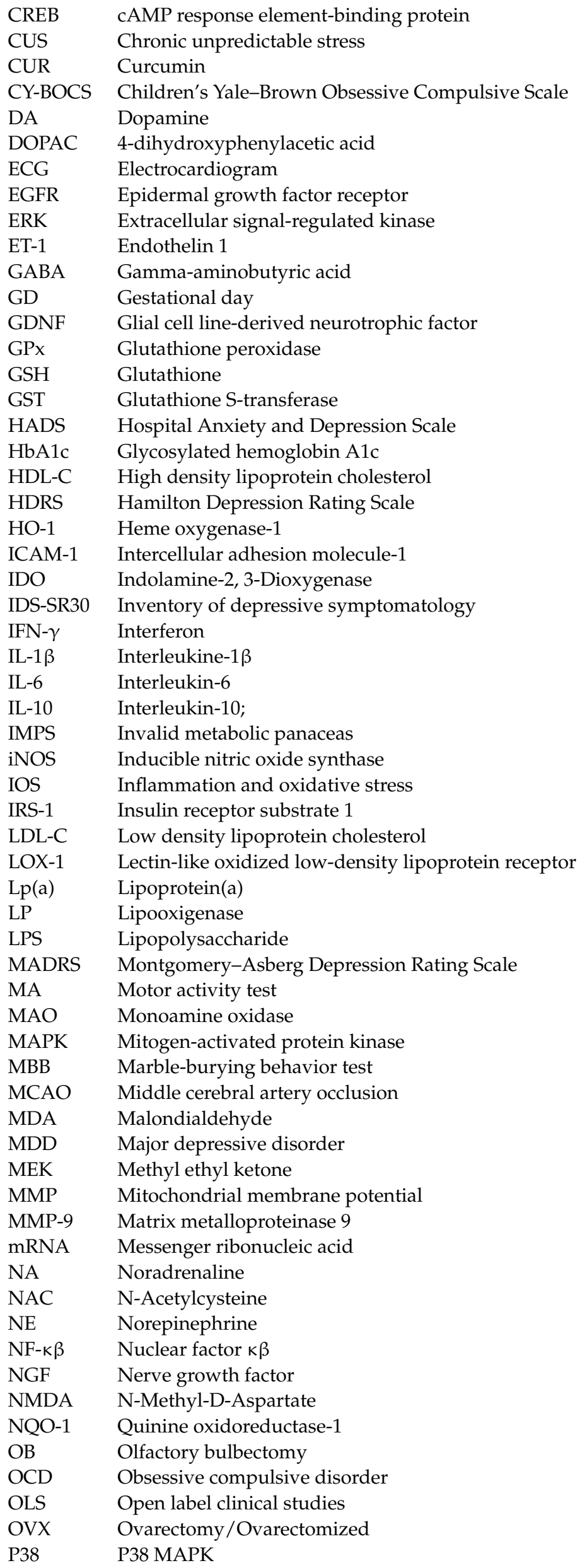




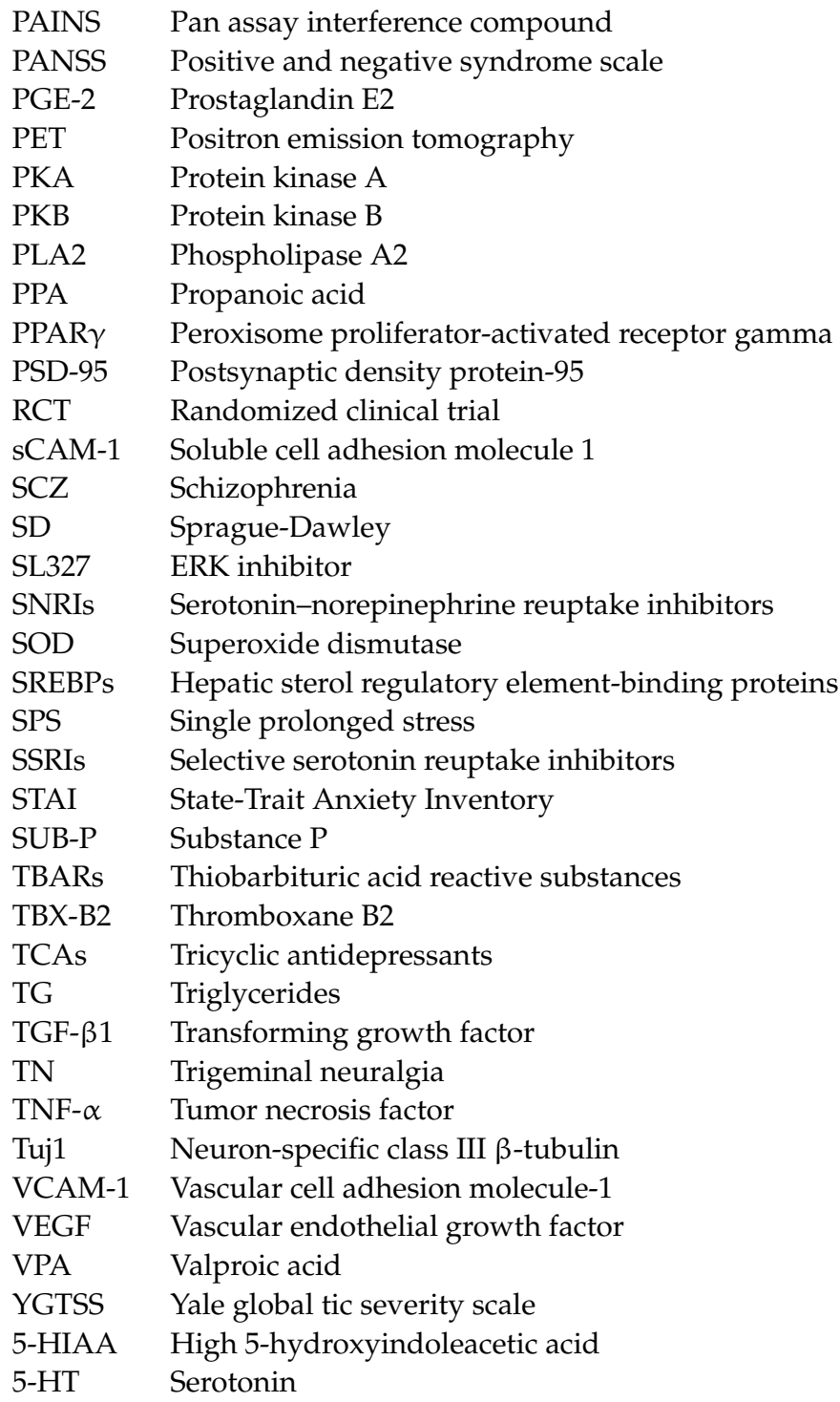

\section{Appendix A}

Search terms used in this non-systematic review were: "curcumin and psychiatry", "curcumin and neurology", "curcumin and brain", "curcumin and inflammation", "curcumin and oxidative stress", "curcumin and schizophrenia", "turmeric and schizophrenia", "curcumin and psychosis", "curcumin and depression", "curcumin and major depressive disorder", "curcumin and MDD" "turmeric and depression", "curcumin and autism", "turmeric and autism", "curcumin and obsessive-compulsive disorder", "turmeric and obsessive-compulsive disorder", "curcumin and OCD".

\section{References}

1. Zhang, H.A.; Kitts, D.D. Turmeric and its bioactive constituents trigger cell signaling mechanisms that protect against diabetes and cardiovascular diseases. Mol. Cell. Biochem. 2021, 476, 3785-3814. [CrossRef] [PubMed]

2. Di Meo, F.; Margarucci, S.; Galderisi, U.; Crispi, S.; Peluso, G. Curcumin, Gut Microbiota, and Neuroprotection. Nutrients 2019, 11, 2426. [CrossRef]

3. Phumsuay, R.; Muangnoi, C.; Wasana, P.W.D.; Hasriadi, H.; Vajragupta, O.; Rojsitthisak, P.; Towiwat, P. Molecular Insight into the Anti-Inflammatory Effects of the Curcumin Ester Prodrug Curcumin Diglutaric Acid In Vitro and In Vivo. Int. J. Mol. Sci. 2020, 21, 5700. [CrossRef]

4. Askarizadeh, A.; Barreto, G.E.; Henney, N.C.; Majeed, M.; Sahebkar, A. Neuroprotection by curcumin: A review on brain delivery strategies. Int. J. Pharm. 2020, 585, 119476. [CrossRef] [PubMed] 
5. Bhat, A.; Mahalakshmi, A.M.; Ray, B.; Tuladhar, S.; Hediyal, T.A.; Manthiannem, E.; Padamati, J.; Chandra, R.; Chidambaram, S.B.; Sakharkar, M.K. Benefits of curcumin in brain disorders. BioFactors 2019, 45, 666-689. [CrossRef] [PubMed]

6. Wang, X.; Hang, Y.; Liu, J.; Hou, Y.; Wang, N.; Wang, M. Anticancer effect of curcumin inhibits cell growth through miR21/PTEN/Akt pathway in breast cancer cell. Oncol. Lett. 2017, 13, 4825-4831. [CrossRef] [PubMed]

7. Bielak-Zmijewska, A.; Grabowska, W.; Ciolko, A.; Bojko, A.; Mosieniak, G.; Bijoch, L.; Sikora, E. The Role of Curcumin in the Modulation of Ageing. Int. J. Mol. Sci. 2019, 20, 1239. [CrossRef]

8. Concetta Scuto, M.; Mancuso, C.; Tomasello, B.; Laura Ontario, M.; Cavallaro, A.; Frasca, F.; Maiolino, L.; Trovato Salinaro, A.; Calabrese, E.J.; Calabrese, V. Curcumin, Hormesis and the Nervous System. Nutrients 2019, 11, 2417. [CrossRef]

9. Chuengsamarn, S.; Rattanamongkolgul, S.; Luechapudiporn, R.; Phisalaphong, C.; Jirawatnotai, S. Curcumin extract for prevention of type 2 diabetes. Diabetes Care 2012, 35, 2121-2127. [CrossRef]

10. Abdollahi, E.; Momtazi, A.A.; Johnston, T.P.; Sahebkar, A. Therapeutic effects of curcumin in inflammatory and immune-mediated diseases: A nature-made jack-of-all-trades? J. Cell. Physiol. 2018, 233, 830-848. [CrossRef]

11. Pivari, F.; Mingione, A.; Brasacchio, C.; Soldati, L. Curcumin and Type 2 Diabetes Mellitus: Prevention and Treatment. Nutrients 2019, 11, 1837. [CrossRef]

12. Salehi, B.; Stojanovic-Radic, Z.; Matejic, J.; Sharifi-Rad, M.; Anil Kumar, N.V.; Martins, N.; Sharifi-Rad, J. The therapeutic potential of curcumin: A review of clinical trials. Eur. J. Med. Chem. 2019, 163, 527-545. [CrossRef]

13. Barbalho, S.M.; de Sousa Gonzaga, H.F.; de Souza, G.A.; de Alvares Goulart, R.; de Sousa Gonzaga, M.L.; de Alvarez Rezende, B. Dermatological effects of Curcuma species: A systematic review. Clin. Exp. Dermatol. 2021, 46, 825-833. [CrossRef]

14. Liu, W.; Zhai, Y.; Heng, X.; Che, F.Y.; Chen, W.; Sun, D.; Zhai, G. Oral bioavailability of curcumin: Problems and advancements. J. Drug Target. 2016, 24, 694-702. [CrossRef]

15. Prasad, S.; Tyagi, A.K.; Aggarwal, B.B. Recent developments in delivery, bioavailability, absorption and metabolism of curcumin: The golden pigment from golden spice. Cancer Res. Treat. 2014, 46, 2-18. [CrossRef] [PubMed]

16. Dei Cas, M.; Ghidoni, R. Dietary Curcumin: Correlation between Bioavailability and Health Potential. Nutrients 2019, 11, 2147. [CrossRef] [PubMed]

17. Nelson, K.M.; Dahlin, J.L.; Bisson, J.; Graham, J.; Pauli, G.F.; Walters, M.A. The Essential Medicinal Chemistry of Curcumin. J. Med. Chem. 2017, 60, 1620-1637. [CrossRef] [PubMed]

18. Baell, J.; Walters, M.A. Chemistry: Chemical con artists foil drug discovery. Nature 2014, 513, 481-483. [CrossRef]

19. Dey, P. Gut microbiota in phytopharmacology: A comprehensive overview of concepts, reciprocal interactions, biotransformations and mode of actions. Pharmacol. Res. 2019, 147, 104367. [CrossRef]

20. Kumar Singh, A.; Cabral, C.; Kumar, R.; Ganguly, R.; Kumar Rana, H.; Gupta, A.; Rosaria Lauro, M.; Carbone, C.; Reis, F.; Pandey, A.K. Beneficial Effects of Dietary Polyphenols on Gut Microbiota and Strategies to Improve Delivery Efficiency. Nutrients 2019, 11, 2216. [CrossRef]

21. Witika, B.A.; Makoni, P.A.; Matafwali, S.K.; Mweetwa, L.L.; Shandele, G.C.; Walker, R.B. Enhancement of Biological and Pharmacological Properties of an Encapsulated Polyphenol: Curcumin. Molecules 2021, 26, 4244. [CrossRef]

22. Moballegh Nasery, M.; Abadi, B.; Poormoghadam, D.; Zarrabi, A.; Keyhanvar, P.; Khanbabaei, H.; Ashrafizadeh, M.; Mohammadinejad, R.; Tavakol, S.; Sethi, G. Curcumin Delivery Mediated by Bio-Based Nanoparticles: A Review. Molecules 2020, $25,689$. [CrossRef]

23. Tran, T.H.; Mattheolabakis, G.; Aldawsari, H.; Amiji, M. Exosomes as nanocarriers for immunotherapy of cancer and inflammatory diseases. Clin. Immunol. 2015, 160, 46-58. [CrossRef]

24. Bonaccorso, A.; Gigliobianco, M.R.; Pellitteri, R.; Santonocito, D.; Carbone, C.; Di Martino, P.; Puglisi, G.; Musumeci, T. Optimization of Curcumin Nanocrystals as Promising Strategy for Nose-to-Brain Delivery Application. Pharmaceutics 2020, 12, 476. [CrossRef] [PubMed]

25. Don, T.M.; Chang, W.J.; Jheng, P.R.; Huang, Y.C.; Chuang, E.Y. Curcumin-laden dual-targeting fucoidan/chitosan nanocarriers for inhibiting brain inflammation via intranasal delivery. Int. J. Biol. Macromol. 2021, 181, 835-846. [CrossRef]

26. Jiang, T.; Liao, W.; Charcosset, C. Recent advances in encapsulation of curcumin in nanoemulsions: A review of encapsulation technologies, bioaccessibility and applications. Food Res. Int. 2020, 132, 109035. [CrossRef] [PubMed]

27. Shireen, E. Experimental treatment of antipsychotic-induced movement disorders. J. Exp. Pharmacol. 2016, 8, 1-10. [CrossRef] [PubMed]

28. Pillai, A.; Parikh, V.; Terry, A.V., Jr.; Mahadik, S.P. Long-term antipsychotic treatments and crossover studies in rats: Differential effects of typical and atypical agents on the expression of antioxidant enzymes and membrane lipid peroxidation in rat brain. $J$. Psychiatr. Res. 2007, 41, 372-386. [CrossRef]

29. Naserzadeh, P.; Hafez, A.A.; Abdorahim, M.; Abdollahifar, M.A.; Shabani, R.; Peirovi, H.; Simchi, A.; Ashtari, K. Curcumin loading potentiates the neuroprotective efficacy of $\mathrm{Fe}_{3} \mathrm{O}_{4}$ magnetic nanoparticles in cerebellum cells of schizophrenic rats. Biomed. Pharmacother. 2018, 108, 1244-1252. [CrossRef]

30. Moghaddam, A.H.; Maboudi, K.; Bavaghar, B.; Sangdehi, S.R.M.; Zare, M. Neuroprotective effects of curcumin-loaded nanophytosome on ketamine-induced schizophrenia-like behaviors and oxidative damage in male mice. Neurosci. Lett. 2021, 765,136249 . [CrossRef] 
31. Wynn, J.K.; Green, M.F.; Hellemann, G.; Karunaratne, K.; Davis, M.C.; Marder, S.R. The effects of curcumin on brain-derived neurotrophic factor and cognition in schizophrenia: A randomized controlled study. Schizophr. Res. 2018, 195, 572-573. [CrossRef] [PubMed]

32. Hosseininasab, M.; Zarghami, M.; Mazhari, S.; Salehifar, E.; Moosazadeh, M.; Fariborzifar, A.; Babaeirad, S.; Hendouei, N. Nanocurcumin as an Add-on to Antipsychotic Drugs for Treatment of Negative Symptoms in Patients With Chronic Schizophrenia: A Randomized, Double-Blind, Placebo-Controlled Study. J. Clin. Psychopharmacol. 2021, 41, 25-30. [CrossRef] [PubMed]

33. Kucukgoncu, S.; Guloksuz, S.; Tek, C. Effects of Curcumin on Cognitive Functioning and Inflammatory State in Schizophrenia: A Double-Blind, Placebo-Controlled Pilot Trial. J. Clin. Psychopharmacol. 2019, 39, 182-184. [CrossRef] [PubMed]

34. Miodownik, C.; Lerner, V.; Kudkaeva, N.; Lerner, P.P.; Pashinian, A.; Bersudsky, Y.; Eliyahu, R.; Kreinin, A.; Bergman, J. Curcumin as Add-On to Antipsychotic Treatment in Patients With Chronic Schizophrenia: A Randomized, Double-Blind, Placebo-Controlled Study. Clin. Neuropharmacol. 2019, 42, 117-122. [CrossRef]

35. Wang, R.; Xu, Y.; Wu, H.L.; Li, Y.B.; Li, Y.H.; Guo, J.B.; Li, X.J. The antidepressant effects of curcumin in the forced swimming test involve 5-HT1 and 5-HT2 receptors. Eur. J. Pharmacol. 2008, 578, 43-50. [CrossRef]

36. Zhang, L.; Xu, T.; Wang, S.; Yu, L.; Liu, D.; Zhan, R.; Yu, S.Y. Curcumin produces antidepressant effects via activating MAPK/ERKdependent brain-derived neurotrophic factor expression in the amygdala of mice. Behav. Brain Res. 2012, 235, 67-72. [CrossRef] [PubMed]

37. Zhang, L.; Xu, T.; Wang, S.; Yu, L.; Liu, D.; Zhan, R.; Yu, S.Y. NMDA GluN2B receptors involved in the antidepressant effects of curcumin in the forced swim test. Prog. Neuro-Psychopharmacol. Biol. Psychiatry 2013, 40, 12-17. [CrossRef]

38. He, X.; Yang, L.; Wang, M.; Zhuang, X.; Huang, R.; Zhu, R.; Wang, S. Targeting the Endocannabinoid/CB1 Receptor System For Treating Major Depression Through Antidepressant Activities of Curcumin and Dexanabinol-Loaded Solid Lipid Nanoparticles. Cell. Physiol. Biochem. Int. J. Exp. Cell. Physiol. Biochem. Pharmacol. 2017, 42, 2281-2294. [CrossRef]

39. Choi, G.Y.; Kim, H.B.; Hwang, E.S.; Lee, S.; Kim, M.J.; Choi, J.Y.; Lee, S.O.; Kim, S.S.; Park, J.H. Curcumin Alters Neural Plasticity and Viability of Intact Hippocampal Circuits and Attenuates Behavioral Despair and COX-2 Expression in Chronically Stressed Rats. Mediat. Inflamm. 2017, 2017, 6280925. [CrossRef]

40. Abd-Rabo, M.M.; Georgy, G.S.; Saied, N.M.; Hassan, W.A. Involvement of the serotonergic system and neuroplasticity in the antidepressant effect of curcumin in ovariectomized rats: Comparison with oestradiol and fluoxetine. Phytother. Res. PTR 2019, 33, 387-396. [CrossRef]

41. Mohammed, H.S.; Khadrawy, Y.A.; El-Sherbini, T.M.; Amer, H.M. Electrocortical and Biochemical Evaluation of Antidepressant Efficacy of Formulated Nanocurcumin. Appl. Biochem. Biotechnol. 2019, 187, 1096-1112. [CrossRef] [PubMed]

42. He, X.L.; Yang, L.; Wang, Z.J.; Huang, R.Q.; Zhu, R.R.; Cheng, L.M. Solid lipid nanoparticles loading with curcumin and dexanabinol to treat major depressive disorder. Neural Regen. Res. 2021, 16, 537-542. [CrossRef] [PubMed]

43. Khadrawy, Y.A.; Hosny, E.N.; Magdy, M.; Mohammed, H.S. Antidepressant effects of curcumin-coated iron oxide nanoparticles in a rat model of depression. Eur. J. Pharmacol. 2021, 908, 174384. [CrossRef] [PubMed]

44. Kulkarni, S.K.; Bhutani, M.K.; Bishnoi, M. Antidepressant activity of curcumin: Involvement of serotonin and dopamine system. Psychopharmacology 2008, 201, 435-442. [CrossRef]

45. Bhutani, M.K.; Bishnoi, M.; Kulkarni, S.K. Anti-depressant like effect of curcumin and its combination with piperine in unpredictable chronic stress-induced behavioral, biochemical and neurochemical changes. Pharmacol. Biochem. Behav. 2009, 92, 39-43. [CrossRef]

46. He, X.; Zhu, Y.; Wang, M.; Jing, G.; Zhu, R.; Wang, S. Antidepressant effects of curcumin and HU-211 coencapsulated solid lipid nanoparticles against corticosterone-induced cellular and animal models of major depression. Int. J. Nanomed. 2016, 11, 4975-4990. [CrossRef]

47. Hurley, L.L.; Akinfiresoye, L.; Nwulia, E.; Kamiya, A.; Kulkarni, A.A.; Tizabi, Y. Antidepressant-like effects of curcumin in WKY rat model of depression is associated with an increase in hippocampal BDNF. Behav. Brain Res. 2013, 239, 27-30. [CrossRef]

48. Kulkarni, S.K.; Akula, K.K.; Deshpande, J. Evaluation of antidepressant-like activity of novel water-soluble curcumin formulations and St. John's wort in behavioral paradigms of despair. Pharmacology 2012, 89, 83-90. [CrossRef]

49. Xu, Y.; Ku, B.S.; Yao, H.Y.; Lin, Y.H.; Ma, X.; Zhang, Y.H.; Li, X.J. Antidepressant effects of curcumin in the forced swim test and olfactory bulbectomy models of depression in rats. Pharmacol. Biochem. Behav. 2005, 82, 200-206. [CrossRef]

50. Borre, Y.E.; Panagaki, T.; Koelink, P.J.; Morgan, M.E.; Hendriksen, H.; Garssen, J.; Kraneveld, A.D.; Olivier, B.; Oosting, R.S Neuroprotective and cognitive enhancing effects of a multi-targeted food intervention in an animal model of neurodegeneration and depression. Neuropharmacology 2014, 79, 738-749. [CrossRef]

51. Rinwa, P.; Kumar, A.; Garg, S. Suppression of neuroinflammatory and apoptotic signaling cascade by curcumin alone and in combination with piperine in rat model of olfactory bulbectomy induced depression. PLoS ONE 2013, 8, e61052. [CrossRef]

52. Jiang, H.; Wang, Z.; Wang, Y.; Xie, K.; Zhang, Q.; Luan, Q.; Chen, W.; Liu, D. Antidepressant-like effects of curcumin in chronic mild stress of rats: Involvement of its anti-inflammatory action. Prog. Neuro-Psychopharmacol. Biol. Psychiatry 2013, 47, 33-39. [CrossRef] [PubMed]

53. Lin, Z.; Shi, L.; Lu, J.; Li, J.; Hu, H.; Zuo, C.; Tang, W.; Lu, Y.; Bao, A.; Xu, L. Effects of curcumin on glucose metabolism in the brains of rats subjected to chronic unpredictable stress: A 18 F-FDG micro-PET study. BMC Complementary Altern. Med. 2013, 14, 202. [CrossRef] [PubMed] 
54. Liu, D.; Wang, Z.; Gao, Z.; Xie, K.; Zhang, Q.; Jiang, H.; Pang, Q. Effects of curcumin on learning and memory deficits, BDNF, and ERK protein expression in rats exposed to chronic unpredictable stress. Behav. Brain Res. 2014, 271, 116-121. [CrossRef] [PubMed]

55. Chang, X.R.; Wang, L.; Li, J.; Wu, D.S. Analysis of anti-depressant potential of curcumin against depression induced male albino wistar rats. Brain Res. 2016, 1642, 219-225. [CrossRef] [PubMed]

56. Cui, M.; Li, Q.; Zhang, M.; Zhao, Y.J.; Huang, F.; Chen, Y.J. Long-term curcumin treatment antagonizes masseter muscle alterations induced by chronic unpredictable mild stress in rats. Arch. Oral Biol. 2014, 59, 258-267. [CrossRef] [PubMed]

57. Haider, S.; Naqvi, F.; Batool, Z.; Tabassum, S.; Sadir, S.; Liaquat, L.; Naqvi, F.; Zuberi, N.A.; Shakeel, H.; Perveen, T. Pretreatment with curcumin attenuates anxiety while strengthens memory performance after one short stress experience in male rats. Brain Res. Bull. 2015, 115, 1-8. [CrossRef] [PubMed]

58. Zhang, L.; Luo, J.; Zhang, M.; Yao, W.; Ma, X.; Yu, S.Y. Effects of curcumin on chronic, unpredictable, mild, stress-induced depressive-like behaviour and structural plasticity in the lateral amygdala of rats. Int. J. Neuropsychopharmacol. 2014, 17, 793-806. [CrossRef]

59. Demir, E.A.; Oz, M.; Alp, M.I.; Gergerlioglu, H.S.; Nurullahoglu, K.E.; Yerlikaya, F.H. Co-administration of cisplatin and curcumin does not alter mood-associated behaviors. Bratisl. Lek. Listy 2016, 117, 106-111. [CrossRef]

60. Vasileva, L.V.; Saracheva, K.E.; Ivanovska, M.V.; Petrova, A.P.; Marchev, A.S.; Georgiev, M.I.; Murdjeva, M.A.; Getova, D.P. Antidepressant-like effect of salidroside and curcumin on the immunoreactivity of rats subjected to a chronic mild stress model. Food Chem. Toxicol. 2018, 121, 604-611. [CrossRef]

61. Lee, B.; Lee, H. Systemic Administration of Curcumin Affect Anxiety-Related Behaviors in a Rat Model of Posttraumatic Stress Disorder via Activation of Serotonergic Systems. Evid.-Based Complementary Altern. Med. 2018, 2018, 9041309. [CrossRef] [PubMed]

62. Liao, D.; Lv, C.; Cao, L.; Yao, D.; Wu, Y.; Long, M.; Liu, N.; Jiang, P. Curcumin Attenuates Chronic Unpredictable Mild StressInduced Depressive-Like Behaviors via Restoring Changes in Oxidative Stress and the Activation of Nrf2 Signaling Pathway in Rats. Oxidative Med. Cell. Longev. 2020, 2020, 9268083. [CrossRef]

63. Saied, N.M.; Georgy, G.S.; Hussien, R.M.; Hassan, W.A. Neuromodulatory effect of curcumin on catecholamine systems and inflammatory cytokines in ovariectomized female rats. Clin. Exp. Pharmacol. Physiol. 2021, 48, 337-346. [CrossRef]

64. Mohammad Abu-Taweel, G.; Al-Fifi, Z. Protective effects of curcumin towards anxiety and depression-like behaviors induced mercury chloride. Saudi J. Biol. Sci. 2021, 28, 125-134. [CrossRef] [PubMed]

65. da Silva Marques, J.G.; Antunes, F.T.T.; da Silva Brum, L.F.; Pedron, C.; de Oliveira, I.B.; de Barros Falcao Ferraz, A.; Martins, M.I.M.; Dallegrave, E.; de Souza, A.H. Adaptogenic effects of curcumin on depression induced by moderate and unpredictable chronic stress in mice. Behav. Brain Res. 2021, 399, 113002. [CrossRef] [PubMed]

66. Rubab, S.; Naeem, K.; Rana, I.; Khan, N.; Afridi, M.; Ullah, I.; Shah, F.A.; Sarwar, S.; Din, F.U.; Choi, H.I.; et al. Enhanced neuroprotective and antidepressant activity of curcumin-loaded nanostructured lipid carriers in lipopolysaccharide-induced depression and anxiety rat model. Int. J. Pharm. 2021, 603, 120670. [CrossRef]

67. Huang, Z.; Zhong, X.M.; Li, Z.Y.; Feng, C.R.; Pan, A.J.; Mao, Q.Q. Curcumin reverses corticosterone-induced depressive-like behavior and decrease in brain BDNF levels in rats. Neurosci. Lett. 2011, 493, 145-148. [CrossRef]

68. Li, Y.C.; Wang, F.M.; Pan, Y.; Qiang, L.Q.; Cheng, G.; Zhang, W.Y.; Kong, L.D. Antidepressant-like effects of curcumin on serotonergic receptor-coupled AC-cAMP pathway in chronic unpredictable mild stress of rats. Prog. Neuro-Psychopharmacol. Biol. Psychiatry 2009, 33, 435-449. [CrossRef]

69. Wang, Z.; Zhang, Q.; Yuan, L.; Wang, S.; Liu, L.; Yang, X.; Li, G.; Liu, D. The effects of curcumin on depressive-like behavior in mice after lipopolysaccharide administration. Behav. Brain Res. 2014, 274, 282-290. [CrossRef]

70. Fan, C.; Song, Q.; Wang, P.; Li, Y.; Yang, M.; Liu, B.; Yu, S.Y. Curcumin Protects Against Chronic Stress-induced Dysregulation of Neuroplasticity and Depression-like Behaviors via Suppressing IL-1beta Pathway in Rats. Neuroscience 2018, 392, 92-106. [CrossRef]

71. Fan, C.; Song, Q.; Wang, P.; Li, Y.; Yang, M.; Yu, S.Y. Neuroprotective Effects of Curcumin on IL-1beta-Induced Neuronal Apoptosis and Depression-Like Behaviors Caused by Chronic Stress in Rats. Front. Cell. Neurosci. 2018, 12, 516. [CrossRef] [PubMed]

72. Madiha, S.; Haider, S. Curcumin restores rotenone induced depressive-like symptoms in animal model of neurotoxicity: Assessment by social interaction test and sucrose preference test. Metab. Brain Dis. 2019, 34, 297-308. [CrossRef]

73. Shen, J.D.; Wei, Y.; Li, Y.J.; Qiao, J.Y.; Li, Y.C. Curcumin reverses the depressive-like behavior and insulin resistance induced by chronic mild stress. Metab. Brain Dis. 2017, 32, 1163-1172. [CrossRef] [PubMed]

74. Wang, Z.; Ren, W.; Zhao, F.; Han, Y.; Liu, C.; Jia, K. Curcumin amends $\mathrm{Ca}(2+)$ dysregulation in microglia by suppressing the activation of P2 $\times 7$ receptor. Mol. Cell. Biochem. 2020, 465, 65-73. [CrossRef] [PubMed]

75. Zhang, L.; Ma, Z.; Wu, Z.; Jin, M.; An, L.; Xue, F. Curcumin Improves Chronic Pain Induced Depression Through Regulating Serum Metabolomics in a Rat Model of Trigeminal Neuralgia. J. Pain Res. 2020, 13, 3479-3492. [CrossRef] [PubMed]

76. Zhang, W.Y.; Guo, Y.J.; Han, W.X.; Yang, M.Q.; Wen, L.P.; Wang, K.Y.; Jiang, P. Curcumin relieves depressive-like behaviors via inhibition of the NLRP3 inflammasome and kynurenine pathway in rats suffering from chronic unpredictable mild stress. Int. Immunopharmacol. 2019, 67, 138-144. [CrossRef] [PubMed]

77. Afzal, A.; Batool, Z.; Sadir, S.; Liaquat, L.; Shahzad, S.; Tabassum, S.; Ahmad, S.; Kamil, N.; Perveen, T.; Haider, S. Therapeutic Potential of Curcumin in Reversing the Depression and Associated Pseudodementia via Modulating Stress Hormone, Hippocampal Neurotransmitters, and BDNF Levels in Rats. Neurochem. Res. 2021, 46, 3273-3285. [CrossRef] 
78. Xu, Y.; Ku, B.; Tie, L.; Yao, H.; Jiang, W.; Ma, X.; Li, X. Curcumin reverses the effects of chronic stress on behavior, the HPA axis, BDNF expression and phosphorylation of CREB. Brain Res. 2006, 1122, 56-64. [CrossRef]

79. Yohn, S.E.; Gorka, D.; Mistry, A.; Collins, S.; Qian, E.; Correa, M.; Manchanda, A.; Bogner, R.H.; Salamone, J.D. Oral Ingestion and Intraventricular Injection of Curcumin Attenuates the Effort-Related Effects of the VMAT-2 Inhibitor Tetrabenazine: Implications for Motivational Symptoms of Depression. J. Nat. Prod. 2017, 80, 2839-2844. [CrossRef]

80. Lian, L.; Xu, Y.; Zhang, J.; Yu, Y.; Zhu, N.; Guan, X.; Huang, H.; Chen, R.; Chen, J.; Shi, G.; et al. Antidepressant-like effects of a novel curcumin derivative J147: Involvement of 5-HT1A receptor. Neuropharmacology 2018, 135, 506-513. [CrossRef]

81. Xu, Y.; Ku, B.S.; Yao, H.Y.; Lin, Y.H.; Ma, X.; Zhang, Y.H.; Li, X.J. The effects of curcumin on depressive-like behaviors in mice. Eur. J. Pharmacol. 2005, 518, 40-46. [CrossRef] [PubMed]

82. Yusuf, M.; Khan, M.; Khan, R.A.; Maghrabi, I.A.; Ahmed, B. Polysorbate-80-coated, polymeric curcumin nanoparticles for in vivo anti-depressant activity across BBB and envisaged biomolecular mechanism of action through a proposed pharmacophore model. J. Microencapsul. 2016, 33, 646-655. [CrossRef] [PubMed]

83. Zhao, X.; Wang, C.; Zhang, J.F.; Liu, L.; Liu, A.M.; Ma, Q.; Zhou, W.H.; Xu, Y. Chronic curcumin treatment normalizes depression-like behaviors in mice with mononeuropathy: Involvement of supraspinal serotonergic system and GABAA receptor. Psychopharmacology 2014, 231, 2171-2187. [CrossRef] [PubMed]

84. Fidelis, E.M.; Savall, A.S.P.; da Luz Abreu, E.; Carvalho, F.; Teixeira, F.E.G.; Haas, S.E.; Bazanella Sampaio, T.; Pinton, S. Curcumin-Loaded Nanocapsules Reverses the Depressant-Like Behavior and Oxidative Stress Induced by beta-Amyloid in Mice. Neuroscience 2019, 423, 122-130. [CrossRef] [PubMed]

85. Li, J.; Chen, L.; Li, G.; Chen, X.; Hu, S.; Zheng, L.; Luria, V.; Lv, J.; Sun, Y.; Xu, Y.; et al. Sub-Acute Treatment of Curcumin Derivative J147 Ameliorates Depression-Like Behavior Through 5-HT1A-Mediated cAMP Signaling. Front. Neurosci. 2020, 14, 701. [CrossRef]

86. Pan, X.; Chen, L.; Xu, W.; Bao, S.; Wang, J.; Cui, X.; Gao, S.; Liu, K.; Avasthi, S.; Zhang, M.; et al. Activation of monoaminergic system contributes to the antidepressant- and anxiolytic-like effects of J147. Behav. Brain Res. 2021, 411, 113374. [CrossRef]

87. Qi, X.J.; Liu, X.Y.; Tang, L.M.; Li, P.F.; Qiu, F.; Yang, A.H. Anti-depressant effect of curcumin-loaded guanidine-chitosan thermo-sensitive hydrogel by nasal delivery. Pharm. Dev. Technol. 2020, 25, 316-325. [CrossRef]

88. Choudhary, K.M.; Mishra, A.; Poroikov, V.V.; Goel, R.K. Ameliorative effect of Curcumin on seizure severity, depression like behavior, learning and memory deficit in post-pentylenetetrazole-kindled mice. Eur. J. Pharmacol. 2013, 704, 33-40. [CrossRef]

89. Ceremuga, T.E.; Helmrick, K.; Kufahl, Z.; Kelley, J.; Keller, B.; Philippe, F.; Golder, J.; Padron, G. Investigation of the Anxiolytic and Antidepressant Effects of Curcumin, a Compound From Turmeric (Curcuma longa), in the Adult Male Sprague-Dawley Rat. Holist. Nurs. Pract. 2017, 31, 193-203. [CrossRef]

90. Xu, Y.; Ku, B.; Cui, L.; Li, X.; Barish, P.A.; Foster, T.C.; Ogle, W.O. Curcumin reverses impaired hippocampal neurogenesis and increases serotonin receptor 1A mRNA and brain-derived neurotrophic factor expression in chronically stressed rats. Brain Res. 2007, 1162, 9-18. [CrossRef]

91. Arora, V.; Kuhad, A.; Tiwari, V.; Chopra, K. Curcumin ameliorates reserpine-induced pain-depression dyad: Behavioural, biochemical, neurochemical and molecular evidences. Psychoneuroendocrinology 2011, 36, 1570-1581. [CrossRef] [PubMed]

92. Sanmukhani, J.; Satodia, V.; Trivedi, J.; Patel, T.; Tiwari, D.; Panchal, B.; Goel, A.; Tripathi, C.B. Efficacy and safety of curcumin in major depressive disorder: A randomized controlled trial. Phytother. Res.: PTR 2014, 28, 579-585. [CrossRef] [PubMed]

93. Bergman, J.; Miodownik, C.; Bersudsky, Y.; Sokolik, S.; Lerner, P.P.; Kreinin, A.; Polakiewicz, J.; Lerner, V. Curcumin as an add-on to antidepressive treatment: A randomized, double-blind, placebo-controlled, pilot clinical study. Clin. Neuropharmacol. 2013, 36, 73-77. [CrossRef]

94. Lopresti, A.L.; Maes, M.; Maker, G.L.; Hood, S.D.; Drummond, P.D. Curcumin for the treatment of major depression: A randomised, double-blind, placebo controlled study. J. Affect. Disord. 2014, 167, 368-375. [CrossRef] [PubMed]

95. Lopresti, A.L.; Maes, M.; Meddens, M.J.; Maker, G.L.; Arnoldussen, E.; Drummond, P.D. Curcumin and major depression: A randomised, double-blind, placebo-controlled trial investigating the potential of peripheral biomarkers to predict treatment response and antidepressant mechanisms of change. Eur. Neuropsychopharmacol. J. Eur. Coll. Neuropsychopharmacol. 2015, 25, 38-50. [CrossRef] [PubMed]

96. Panahi, Y.; Badeli, R.; Karami, G.R.; Sahebkar, A. Investigation of the efficacy of adjunctive therapy with bioavailability-boosted curcuminoids in major depressive disorder. Phytother. Res. 2015, 29, 17-21. [CrossRef] [PubMed]

97. Yu, J.J.; Pei, L.B.; Zhang, Y.; Wen, Z.Y.; Yang, J.L. Chronic Supplementation of Curcumin Enhances the Efficacy of Antidepressants in Major Depressive Disorder: A Randomized, Double-Blind, Placebo-Controlled Pilot Study. J. Clin. Psychopharmacol. 2015, 35, 406-410. [CrossRef]

98. Lopresti, A.L.; Drummond, P.D. Efficacy of curcumin, and a saffron/curcumin combination for the treatment of major depression: A randomised, double-blind, placebo-controlled study. J. Affect. Disord. 2017, 207, 188-196. [CrossRef]

99. Kanchanatawan, B.; Tangwongchai, S.; Sughondhabhirom, A.; Suppapitiporn, S.; Hemrunrojn, S.; Carvalho, A.F.; Maes, M. Add-on Treatment with Curcumin Has Antidepressive Effects in Thai Patients with Major Depression: Results of a Randomized Double-Blind Placebo-Controlled Study. Neurotox. Res. 2018, 33, 621-633. [CrossRef]

100. Bhandari, R.; Kuhad, A. Neuropsychopharmacotherapeutic efficacy of curcumin in experimental paradigm of autism spectrum disorders. Life Sci. 2015, 141, 156-169. [CrossRef] 
101. Al-Askar, M.; Bhat, R.S.; Selim, M.; Al-Ayadhi, L.; El-Ansary, A. Postnatal treatment using curcumin supplements to amend the damage in VPA-induced rodent models of autism. BMC Complementary Altern. Med. 2017, 17, 259. [CrossRef] [PubMed]

102. Zhong, H.; Xiao, R.; Ruan, R.; Liu, H.; Li, X.; Cai, Y.; Zhao, J.; Fan, X. Neonatal curcumin treatment restores hippocampal neurogenesis and improves autism-related behaviors in a mouse model of autism. Psychopharmacology 2020, 237, 3539-3552. [CrossRef] [PubMed]

103. Jayaprakash, P.; Isaev, D.; Shabbir, W.; Lorke, D.E.; Sadek, B.; Oz, M. Curcumin Potentiates alpha7 Nicotinic Acetylcholine Receptors and Alleviates Autistic-Like Social Deficits and Brain Oxidative Stress Status in Mice. Int. J. Mol. Sci. 2021, $22,7251$. [CrossRef] [PubMed]

104. Liu, Z.; Cui, C.; Xu, P.; Dang, R.; Cai, H.; Liao, D.; Yang, M.; Feng, Q.; Yan, X.; Jiang, P. Curcumin Activates AMPK Pathway and Regulates Lipid Metabolism in Rats Following Prolonged Clozapine Exposure. Front. Neurosci. 2017, 11, 558. [CrossRef] [PubMed]

105. Ong, W.Y.; Farooqui, T.; Kokotos, G.; Farooqui, A.A. Synthetic and natural inhibitors of phospholipases A2: Their importance for understanding and treatment of neurological disorders. ACS Chem. Neurosci. 2015, 6, 814-831. [CrossRef]

106. Ramaholimihaso, T.; Bouazzaoui, F.; Kaladjian, A. Curcumin in Depression: Potential Mechanisms of Action and Current Evidence-A Narrative Review. Front. Psychiatry 2020, 11, 572533. [CrossRef] 